\title{
IL-1-induced Murine Osteoblast IL-6 Production is Mediated by the Type 1 IL-1 Receptor and Is Increased by 1,25 Dihydroxyvitamin $D_{3}$
}

\author{
David L. Lacey, * Leonard E. Grosso, * Stephen A. Moser," Jeanne Erdmann, * \\ Hong-Lin Tan, ${ }^{*}$ Roberto Pacifici, ${ }^{\star}$ and Dennis T. Villareal ${ }^{*}$ \\ * Department of Pathology and ${ }^{\ddagger}$ Division of Metabolism, Jewish Hospital of St. Louis at Washington University, St. Louis, \\ Missouri 63110; and $\$$ Department of Pathology, University of Alabama at Birmingham, Birmingham, Alabama 35233
}

\begin{abstract}
IL-1-induced osteoblast IL-6 production represents one possible mechanism by which IL-1 augments bone resorption. In this report, we show that the murine osteoblastic cell line (MC3T3-E1) expresses type 1 IL-1 receptors based on ${ }^{125} \mathrm{I}-$ HrIL1 $\alpha$ binding, blocked by type 1 IL-1R antibodies (35F5), and analysis of MC3T3 RNA by reverse transcription (RT)DNA amplification and Northern analysis. MC3T3 cells do not express detectable type 2 IL-1R mRNA by RT-DNA amplification. IL-1 induces (IL-1 ED $_{50}, 0.1$ pM) IL-6 production through the type 1 IL-1R as 35F5 antibodies block IL-1-stimulated IL-6 production. Vitamin D3 increases IL-1R expression dose- and metabolite-dependently, with $1,25-(\mathrm{OH})_{2} \mathrm{D}_{3}$ having the greatest potency, and also enhances IL-1's capacity to stimulate IL-6 production at low IL-1 levels. Both IL-1 and 1,25$(\mathrm{OH})_{2} \mathrm{D}_{3}$ induce type $1 \mathrm{IL-1R}$ and not type 2 IL-1R upregulation based on ligand binding and RT-DNA amplification. Increased IL-1R expression requires a 5-7-h treatment and is protein/RNA synthesis dependent. These observations imply that IL-1-induced IL-6 production in osteoblasts is mediated by type 1 IL-1Rs and that increased IL-1R expression could play a role in mediating IL-1-induced skeletal responses. ( $J$. Clin. Invest. 1993. 91:1731-1742.) Key words: type 1 IL-1 receptor - type 2 IL-1 receptor $・$ IL-6 - RT-PCR • vitamin D
\end{abstract}

\section{Introduction}

Osteoblasts are ideally positioned to function as cellular mediators of hormonally regulated skeletal metabolism (1), and increasing evidence suggests that IL-1 effects on the skeleton, including osteoclast activation, are mediated through the osteoblast. IL- $1 \alpha$ and $-\beta$, two of the most potent bone-resorbing factors on a molar basis (2), are cytokines produced primarily, but not solely, by cells of the monocyte-macrophage lineage. Initiated with Gowen's report describing the capacity for IL-1 (or an IL-1-like factor) to stimulate bone resorption in organ cultures, experimental results continue to suggest that IL-1 may serve as an important regulator of bone remodeling (2-4). Furthermore, IL- $1 \beta$ is now considered to be the principal component of osteoclast activating factor: a mixture of factors de-

Address correspondence to David L. Lacey, M.D., Department of Pathology, Jewish Hospital of St. Louis, 216 South Kingshighway, St. Louis, MO 63110.

Received for publication 25 August 1992 and in revised form 13 November 1992.

J. Clin. Invest.

(C) The American Society for Clinical Investigation, Inc.

$0021-9738 / 93 / 04 / 1731 / 12 \$ 2.00$

Volume 91, April 1993, 1731-1742 rived from activation of heterogeneous leukocyte cultures that stimulates bone resorption in organ cultures (5). The physiologic relevance of these in vitro observations has been underscored by the capacity for IL-1 to induce hypercalcemia associated with histologic evidence of increased osteoclastic activity in in vivo studies on rodents $(6,7)$.

In vitro studies using transformed osteoblastic cell lines, primary osteoblast cultures, and nontransformed osteoblast cell lines have documented the capacity for IL-1 to influence a number of osteoblastic matrix-related activities, including cellular proliferation, collagen and osteocalcin synthesis, alkaline phosphatase production, collagenase, and plasminogen activator production ( 8-14). Additionally, osteoblasts are also stimulated by many bone-resorbing substances to secrete cytokines and other factors that can act locally in an autocrine and/or paracrine manner. One such factor is IL-6, which has been shown to influence osteoclast development in vitro (15) and stimulates bone resorption both in vitro (16) and induces hypercalcemia in vivo (17). This cytokine is produced in abundance by osteoblasts after their exposure to IL-1 (16) and is present in elevated amounts in Paget's disease of bone (18), a condition characterized by lytic bone lesions having increased numbers of osteoclasts.

While IL-1-stimulated IL-6 likely plays a role in IL-1-induced bone resorption, aspects of its induction by IL-1 remain undefined. For instance, the cellular effects of IL-1 are mediated by specific high-affinity IL-1 cell surface receptors (IL1R) (19), of which there are two types. Sequences for these two different cell surface IL-1 binding molecules predict membrane receptors with external domains that are characteristic of the immunoglobulin superfamily $(20,21)$. It was originally thought that the type 1 IL-1R was expressed primarily on $T$ cells, fibroblasts, and epithelial cells, whereas IL-1 binding by $B$ cells, macrophages, or bone marrow cells was mediated by type 2 IL-1R(s) $(22,23)$. However, recent data suggest that the segregated distribution of these receptor subtypes to different cell lineages may not be so straightforward (21). In osteoblastic cells, ${ }^{125} \mathrm{I}-\mathrm{IL}-1$ ligand binding studies on a number of osteoblast cell lines and osteoblast primary cultures have documented the presence of high-affinity IL-1 binding sites (24-27); however, it remains unclear which IL-1 R(s) is expressed by osteoblasts. Furthermore, the IL-1R that, when ligand bound, initiates the signal eventuating in IL-6 release is not known.

To address these issues, we have investigated aspects of IL-6 production and IL-1R expression and regulation utilizing MC3T3 cells. This cell line, established from calvaria of newborn $\mathrm{C} 57 \mathrm{Bl} / 6$ mice, is nontransformed and expresses an osteoblastic phenotype (28). As will be shown, nonstimulated MC3T3 cells express a high number of IL-1 binding sites that, based on antibody-blocking experiments and mRNA analysis, are type 1 IL-1Rs. IL-1-induced MC3T3 IL-6 bioactivity is 
stimulated at IL-1 levels far below the IL-1R $K_{\mathrm{d}}$, and the generation of this activity is blocked by anti-type 1 IL-1R antibodies. Both HrIL-1 $\alpha$ and the bone-seeking steroid 1,25-(OH $)_{2} \mathrm{D}_{3}$ augment IL-1R expression in a dose- and time-dependent manner via a mechanism requiring both protein and RNA synthesis. In the case of $1,25-(\mathrm{OH})_{2} \mathrm{D}_{3}$, the vitamin $\mathrm{D}_{3}$ metabolite specificity of the response suggests that the effect is mediated via the vitamin $D_{3}$ receptor. In $1,25-(\mathrm{OH})_{2} \mathrm{D}_{3}$-treated cells, which express a greater number of type 1 IL-1Rs, low levels of IL-1 induce higher levels of IL- 6 and IL- 6 mRNA than in control cells. These data indicate that osteoblastic IL-6 production is mediated by type 1 IL-1Rs and that the regulation of this receptor could play a fundamental role in skeletal metabolism.

\section{Methods}

Media, buffers, and chemicals. The MC3T3 culture medium was the alpha modification of Eagle's MEM supplemented with $2 \mathrm{mM}$ L-glutamine, penicillin/streptomycin $(100 \mathrm{U} / \mathrm{ml}, 100 \mu \mathrm{g} / \mathrm{ml})$ and $5 \%$ heatinactivated fetal calf serum (HIFCS, $\alpha 5$-MEM). ${ }^{1}$ The B9 cell media was RPMI 1640, 2 mM L-glutamine, $25 \mathrm{mM}$ Hepes, penicillin/streptomycin $(100 \mathrm{U} / \mathrm{ml}, 100 \mu \mathrm{g} / \mathrm{ml})$, with $10 \%$ HIFCS. The trypsin/EDTA concentrate (Gibco/BRL, Gaithersburg, MD) was diluted in $\mathrm{Ca}^{++}$/ $\mathrm{Mg}^{++}$-free PBS (TE-PBS). The binding buffer (BB) used in the IL-1R assay was RPMI 1640, $25 \mathrm{mM}$ Hepes ( $\mathrm{pH} 7.2$ ), supplemented with 5\% HIFCS (29). The acid-strip buffer was $130 \mathrm{mM} \mathrm{NaCl}, 20 \mathrm{mM}$ sodium acetate ( $\mathrm{pH}$ 3.0). The buffer used for RNA gels was $20 \mathrm{mM}$ MOPS (3-[ $N$-morpholino]propanesulfonic acid; $\mathrm{pH} 6.8$ ), $5 \mathrm{mM}$ sodium acetate, and $1 \mathrm{mM}$ EDTA. Actinomycin D (ACT D), cycloheximide (CHX), and 3-[4,5-dimethylthiazol-2-yl]-2,5-diphenyltetrazolium bromide (MTT) were obtained from Sigma Chemical Co. (St. Louis, MO).

Cytokines and antibodies. Human recombinant IL- $1 \alpha$ (HrIL-1 $\alpha$ ) supplied as the carboxy-terminal 154 amino acids of the 271-amino acid human IL- $1 \alpha$ precursor was kindly provided by Dr. P. Lomedico (Hoffmann-La Roche, Nutley, NJ). The vitamin $\mathrm{D}_{3}$ metabolites were the kind gift of Milan Uskokovic (Hoffmann-La Roche) and were dissolved as concentrated stock solutions in absolute ethanol and stored in the dark at $-20^{\circ} \mathrm{C}$. The final concentration of ethanol in all experiments was always $<0.01 \%$, an amount that does not affect cellular viability or ${ }^{125} \mathrm{I}-\mathrm{H}$ IL $-1 \alpha$ binding (data not shown). The rat antimurine monoclonal anti-IL-1 receptor antibody $35 \mathrm{~F} 5(1.6 \mathrm{mg} / \mathrm{ml})$, which blocks IL-1 binding to T cells and fibroblasts (type 1 IL-1R) but not to B cells or monocytes (type $2 \mathrm{IL}-1 \mathrm{R}$ ), was kindly provided by $\mathrm{Dr}$. R. Chizzonite (Hoffmann-La Roche) (23). Rat anti-mouse IL-6 monoclonal antibodies were obtained from Genzyme Corp. (Cambridge, MA).

Cells. The MC3T3-E1 (MC3T3) cell line was kindly provided by Dr. H. Tanaka (Okayama University, Okayama, Japan). The cells were maintained in a humidified atmosphere at $37^{\circ} \mathrm{C}$ in $5 \% \mathrm{CO}_{2}$ in air. For cell passage (every 5-7 d), the confluent cell layers were treated with TE-PBS and, after rinsing, seeded at $2 \times 10^{4} \mathrm{cell} / \mathrm{ml}$ in T75 tissue culture flasks ( $15 \mathrm{ml}$ total volume). To ensure that the cells used in our experiments expressed an osteoblastic phenotype, PTH induction of cAMP, monolayer staining for alkaline phosphase activity, and culture morphology were assessed (data not shown). Based on changes in cell layer morphology from a "cobblestone" to a spindled appearance, together with a reduction of alkaline phosphatase activity with increasing

1. Abbreviations used in this paper: $\mathrm{ACT} \mathrm{D}$, actinomycin $\mathrm{D} ; \mathrm{BB}$, binding buffer; $\mathrm{CHX}$, cycloheximide; HIFCS, heat-inactivated FCS; $\mathrm{Hr}$, human recombinant; MTT, 3-[4,5-dimethylthiazol-2-yl]-2,5-diphenyltetrazolium bromide; TE-PBS, trypsin/EDTA concentrate diluted in $\mathrm{Ca}^{++} / \mathrm{Mg}^{++}$-free PBS. passage number, MC3T3 cells were utilized for experiments only up to passage 10.

IL-6-dependent B9 plasmacytoma cells were kindly provided by Dr. Thomas Kupper (Washington University, St. Louis, MO) and were maintained by biweekly passage in $\mathrm{B} 9$ passage media supplemented with IL-1-stimulated ( 1.0 pM HrIL-1 $\alpha, 48$ h) MC3T3 cell conditioned media $(0.1 \%$ final concentration, $\sim 10 \mathrm{U} / \mathrm{ml}$ IL- 6 activity), which is a rich source of murine IL-6 (16).

${ }^{125} \mathrm{I}-\mathrm{HrIL}-\mathrm{l} \alpha$ binding. HrIL- $\alpha$ was labeled with ${ }^{125} \mathrm{I}\left(\mathrm{Na}^{125} \mathrm{I}, \mathrm{ICN}\right)$ using enzymobeads (29) (Bio-Rad Laboratories, Richmond, CA) and the biochemical and biological activity of the preparation verified as described (30). The specific activity of the ligand ranged from 1,400 to $3,000 \mathrm{cpm} / \mathrm{fmol}$. At $T=0, \mathrm{MC} 3 \mathrm{~T} 3$ cells were cultured in 24-well plate wells at a density of $10^{5}$ cells/well in $2 \mathrm{ml}$ of $\alpha 5$-MEM. After $48 \mathrm{~h}$, at which time the cell layer was nearly confluent, the medium was replaced with fresh medium ( $1 \mathrm{ml} /$ well) containing the different treatments and further incubated for an additional $24 \mathrm{~h}$. The MC3T3 cells were then gently rinsed with cold serum-free $B B(\times 3)$. In some experiments, the cells were acid-stripped with acid-strip buffer $(0.5 \mathrm{ml}, 2 \mathrm{~min}$, $22^{\circ} \mathrm{C}$ ) followed by three rinses with serum-free $\mathrm{BB}$ (neutral $\mathrm{pH}$ ). This procedure was effective in removing unlabeled HrIL- $1 \alpha$ from cells previously incubated with a receptor saturating level $\left(1 \mathrm{nM}, 1 \mathrm{~h}, 4^{\circ} \mathrm{C}\right)$ of the cytokine (data not shown). In ligand-binding experiments, $1 \mathrm{nM}$ ${ }^{125}$ I-HrIL- $\alpha$ was used unless otherwise noted and nonspecific binding was determined in the presence of $20 \mathrm{nM}$ HrIL- $1 \alpha$ in a final incubation volume of $0.4 \mathrm{ml}$. After a 1 -h incubation at $4^{\circ} \mathrm{C}(6 \mathrm{~h}$ for Scatchard analysis), the cell layers were rinsed with cold Hanks' buffered salt solution $(6 \times 1 \mathrm{ml})$ and then solubilized by the addition of $0.5 \mathrm{ml} 1 \mathrm{~N}$ $\mathrm{NaOH}$. The cell-associated radioactivity was determined in a gamma counter. Parallel culture wells were trypsinized (TE-PBS) and cell numbers established by counting with a hemocytometer. The data are reported as the mean ( $n=2$ or 3 ) and range or standard deviation, respectively, of the cpm ${ }^{125}$ I-HrIL- $\alpha$ bound $/ 1 \times 10^{5}$ cells. Some of the data were subjected to Scatchard analysis (31).

Reverse transcription/DNA amplification and plasmids. The PCR primer sequences are presented in Table I. For reverse transcription/ DNA amplification (32), 1- or 2- $\mu$ g aliquots total cellular RNA (for purification method, see below) were reverse transcribed using random hexamer primers (200 pmol); $1 \times$ DNA Taq polymerase buffer (Promega Biotec, Madison, WI); $1 \mathrm{mM}$ each dATP, dCTP, dGTP, and dTTP; 20 Units RNasin ribonuclease inhibitor (Promega Biotec); and 200 U MMLV reverse transcriptase (Gibco/BRL). After an initial 10 min at $22^{\circ} \mathrm{C}$, the reaction was adjusted to $42^{\circ} \mathrm{C}$ for $30 \mathrm{~min}$, then heated $\left(95^{\circ} \mathrm{C}, 10 \mathrm{~min}\right)$ and subsequently chilled to $4^{\circ} \mathrm{C}$. At this time, the reagents for Taq DNA polymerase mediated temperature-cycled DNA amplification were added. These were 20 pmol $3^{\prime}$ and $5^{\prime}$ oligomers, 1 $\mathrm{mM} \mathrm{MgCl} 2$ (2.5 mM final), and $1 \mathrm{U}$ Taq DNA polymerase (Promega Biotec) in $1 \times$ Taq DNA polymerase buffer to 50 or $100 \mu$ l. The final dNTP concentration was $0.2 \mathrm{mM}$. The tubes were cycled in a thermocycler (Perkin-Elmer Cetus, Norwalk, CT) with an initial $3 \mathrm{~min}$ at $94^{\circ} \mathrm{C}$ for denaturation followed by 30 cycles $(35$ cycles for the type 2 IL-1R) consisting of $45 \mathrm{~s}$ at $94^{\circ} \mathrm{C}, 1 \mathrm{~min}$ at $60^{\circ} \mathrm{C}$, and $2 \mathrm{~min}$ at $72^{\circ} \mathrm{C}$. After the last cycle, the reactions were incubated for $7 \mathrm{~min}$ at $72^{\circ} \mathrm{C}$. Aliquots were then analyzed on a $3 \%$ composite (Seakem: Nusieve; FMC Corp., Rockland, ME, 1:2) agarose gel in a $89 \mathrm{mM}$ Tris-borate (pH 8.3), $25 \mathrm{mM}$ EDTA buffer containing ethidium bromide $(0.5$ $\mu \mathrm{g} / \mathrm{ml}$ ) utilizing Haell digested $\Phi \mathrm{X} 174$ as a standard (Gibco/BRL).

The inserts used to create plasmids P4ZIL-1R1.5 (type 1 IL-1R) and P4ZII-6 (IL-6) were derived from the DNA amplification products of reverse-transcribed EL4.6.1 (primed with 3' type 1 IL-1R oligomer) and lipopolysaccharide $(5 \mu \mathrm{g} / \mathrm{ml})$-treated $(4 \mathrm{~h})$ peritoneal macrophage (Balb/cByJ) total cell RNA, respectively, using the appropriate primers. After purification from low-melting temperature agarose (Nusieve, FMC), the amplified DNA was blunt-ended with T4 DNA polymerase, co-precipitated $(0.01$ Spermine $\mathrm{HCl}$ ) with SMA 1 (Boehringer Mannheim Biochemicals, Indianapolis, IN) digested PGEM-4Z (Promega Biotec), rinsed in $70 \%$ ethanol/0.03 M sodium acetate, lyophilized, suspended in ligase buffer, heated $\left(65^{\circ} \mathrm{C}\right.$ for $\left.5 \mathrm{~min}\right)$, and 
Table I. PCR Primers

\begin{tabular}{llcc}
\hline \multicolumn{1}{c}{ Gene* } & \multicolumn{1}{c}{ Sequence $^{*}$} & Site & Restriction Fragments $^{5}$ \\
\hline type 1 IL-1R (20)" & 5'-TGGTACAGGGACTCCTGCTCTGGTT & $(1,048-1,072)^{* *}$ & 319,139 \\
& 3'-GTCTCCTGACCAGCAAATGACTCCG & $(1,506-1,482)$ & 44,169 \\
type 2 IL-1R (21)' & 5'-ACTTGCAAATCTCAGCTCTCTCCAC & $(541-565)$ & $(1,155-1,031)$ \\
& 3'-CTTTGACTGTGGTATGGAGTGACTG & $(121-145)$ & Not Applicable \\
IL-6 (53)" & 5'-GTCTATACCACTTCACAAGTCGGAG & $(621-597)$ & \\
& 3'-GGTTTGCCGAGTAGATCTCAAAGTG & & \\
\hline
\end{tabular}

\footnotetext{
* The sequences are from cDNA.

${ }^{\ddagger}$ Order is from 5 ' to 3 '.

${ }^{8}$ Predicted restriction fragment length (in bp) after digestion of the amplified region with Saul (type 1 IL-1R) or PvuII (type 2 IL-1R).

"Synthesized on an oligonucleotide synthesizer (model 3801; Applied Biosystems, Foster City, CA).

'Obtained from Genosys (The Woodlands, TX).

** Sequence range in cDNA.
}

then ligated overnight $\left(14^{\circ} \mathrm{C}\right)$ with $\mathrm{T} 4 \mathrm{DNA}$ ligase. Aliquots of these reactions were used to transform the DH5 $\alpha$ strain (Max Effic $\alpha$; BRL, Gaithersburg, MD) of $E$. coli that were streaked on LB agar supplemented with $50 \mu \mathrm{g} / \mathrm{ml}$ ampicillin, $0.5 \mathrm{mM}$ IPTG, and $40 \mu \mathrm{g} / \mathrm{ml} \mathrm{X-}$ $\mathrm{Gal}$. Selected colonies were cultured in ampicillin $(50 \mu \mathrm{g} / \mathrm{ml})$ containing LB media. The insert sequences of both plasmids were verified utilizing primers complementary to the SP6 and T7 RNA polymerase initiation sites, alkali-denatured, miniprep-plasmid DNA, ${ }^{35} \mathrm{~S} \alpha$-dATP ( $1250 \mathrm{Ci} / \mathrm{mmol}$, DuPont-NEN, Wilmington, DE), Sequenase (USBiochemical Corp., Cleveland, $\mathrm{OH}$ ) in a dideoxy chain termination method according to the manufacturer's instructions.

Type 1 and type $2 I L-1 R m R N A$ assays. To detect the presence of MC3T3 type 1 and type 2 IL-1R mRNA, both reverse transcription/ DNA amplification (32) and Northern blot analysis were used. MC3T3 and CBA/CaJ splenocyte total cellular RNA were prepared by the method of Chirgwin et al. (33), quantified by absorbance spectroscopy $\left(1 A_{260}=40 \mu \mathrm{g} / \mathrm{ml}\right)$, and analyzed on a $1 \%$ Seakem agarose (FMC, Rockland, ME)/formaldehyde ( $0.23 \%)$ gel (34) in Northern buffer to assure RNA integrity. Aliquots of this RNA were then used in reverse transcription/DNA amplification studies using the types 1 and 2 IL-1R primers. Portions of the amplified DNA were restriction digested with SauI or PvulI (Boehringer Mannheim Biochemicals) according to the manufacturer's instructions.

For Northern blots, MC3T3 and/or EL4 6.1 (gift of David Chaplin, Washington University, St. Louis, MO) total cell RNA were electrophoresed in $1 \%$ agarose gels as described above. The RNA was electroblotted onto Zeta probe nylon membranes according to manufacturer's instructions (Biorad Laboratories). The blots were prehybridized in cocktail containing $50 \%$ formamide, $0.25 \mathrm{M} \mathrm{NaHPO}_{4}(\mathrm{pH}$ 7.2), $0.25 \mathrm{M} \mathrm{NaCl}, 1 \mathrm{mM}$ EDTA, and $2 \%$ SDS for $1-2 \mathrm{~h}$ at $42^{\circ} \mathrm{C}$. The type 1 murine IL-1R and IL-6 probes were generated by labeling the gel-purified DNA amplification product of plasmids P4ZIL-1R1.5 or P4ZIL-6 with $\left[{ }^{32} \mathrm{P}\right] \alpha$ dCTP $(3,000 \mathrm{Ci} / \mathrm{mmol}$, ICN Biomedicals Inc., Irvine, CA) by random priming (random primed DNA labeling kit, Boehringer Mannheim Biochemicals). The probe specific activity was estimated at $10^{8}-10^{9} \mathrm{cpm} / \mu \mathrm{g}$ DNA. Hybridization $\left(16-20 \mathrm{~h}, 42^{\circ} \mathrm{C}\right)$ was performed using $10^{6} \mathrm{cpm} / \mathrm{ml}$ probe in the same buffer used for prehybridization. The membranes were then washed three times in $2 \times$ SSC, $0.1 \%$ SDS at room temperature and then once in $0.2 \times$ SSC, $0.1 \%$ SDS at $56^{\circ} \mathrm{C}$ for $1 \mathrm{~h}$. For autoradiography, the blots were exposed to Kodak XAR film at $-80^{\circ} \mathrm{C}$ for $1 \mathrm{wk}$.

IL-6 bioassay. Various dilutions (1:1-1:100,000) of MC3T3-conditioned media (in $100 \mu \mathrm{l}$ ) were prepared in 96-well microtiter plates using $\alpha 5$-MEM as the background media. B9 cells, 3-4 d after last passage, were rinsed once in serum and growth factor-free B9 media, suspended at $1 \times 10^{5}$ cells $/ \mathrm{ml}$ in the same medium supplemented with $5 \%$ HIFCS, and then added (100- $\mu$ l aliquots) to the previously prepared wells. The cultures were incubated for a $72-h$ period. To assess cell growth, the MTT dye conversion assay (35) was used. The data are reported in units $(U)$, with one unit defined as the activity resulting in half-maximal response based on optical density. The standard deviation was $\leq 15 \%$ of the mean. HrIL- $1 \alpha$ had no effects on B9 cellular proliferation at any concentration tested $(0.01-1,000 \mathrm{pM}$, data not shown).

\section{Results}

In the first series of experiments, MC3T3 IL-1Rs were characterized by a number of methods, including ${ }^{125} \mathrm{I}-\mathrm{HrIL}-1 \alpha$ cellsurface binding, antibody-blocking experiments, and mRNA analysis. As shown in Fig. $1 A$, equilibrium binding studies using ${ }^{125} \mathrm{I}-\mathrm{HrIL}-1 \alpha$ demonstrated the presence of saturable HrIL- $1 \alpha$ binding sites. Resolution of the data on Scatchard plots, illustrated in Fig. $1 B$, revealed that the MC3T3 IL-1R $K_{d}$ was $\sim 80 \mathrm{pM}$ and that the number of HrIL-1 $\alpha$ binding sites was $\sim 10,000$ receptor sites/cell.

The next experiments determined the type of IL-1R(s) expressed by this osteoblast cell line. In the first experiment, ${ }^{125} \mathrm{I}$ HrIL-1 $\alpha$ binding studies were performed using either unlabeled HrIL-1 $\alpha$ or 35F5 (23) as competitors for ${ }^{125}$ I-HrIL-1 $\alpha$ binding. As shown in Fig. $2 A$, both HrIL-1 $\alpha(20 \mathrm{nM})$ and -35F5 $(1: 100,16 \mu \mathrm{g} / \mathrm{ml})$ were equally effective at blocking ${ }^{125} \mathrm{I}-$ HrIL- $1 \alpha$ binding, suggesting that the majority of the osteoblastexpressed IL-1Rs were either immunologically closely related or identical to the type 1 IL-1R. Using 25-bp oligomer primers bracketing a 458-bp type 1 IL-1R sequence (20), the presence of type 1 IL-1R mRNA molecules was assessed using a reverse transcriptase-DNA amplification protocol (32). As the ethidium bromide-stained gel demonstrates (Fig. $2 B$ ), the DNA amplified from MC3T3 total RNA electrophoresed as a single band migrating at a point near the predicted product size ( 458 bp). Further confirmation that this DNA band had resulted from amplification of type I IL-1R mRNA was obtained from the capacity of the restriction enzyme SauI ( heptameric restriction site) to completely cleave the amplified DNA into two fragments virtually the size predicted (Table I) by the restriction map of the cDNA corresponding to the amplified region. To verify that the amplified material was not the result of amplification of contaminating DNA, parallel reactions were performed that either lacked reverse transcriptase (Fig. $2 B$, lane $b$ ) or employed murine genomic DNA ( $1 \mu \mathrm{g}$, Fig. $2 B$, lane $c)$ in 

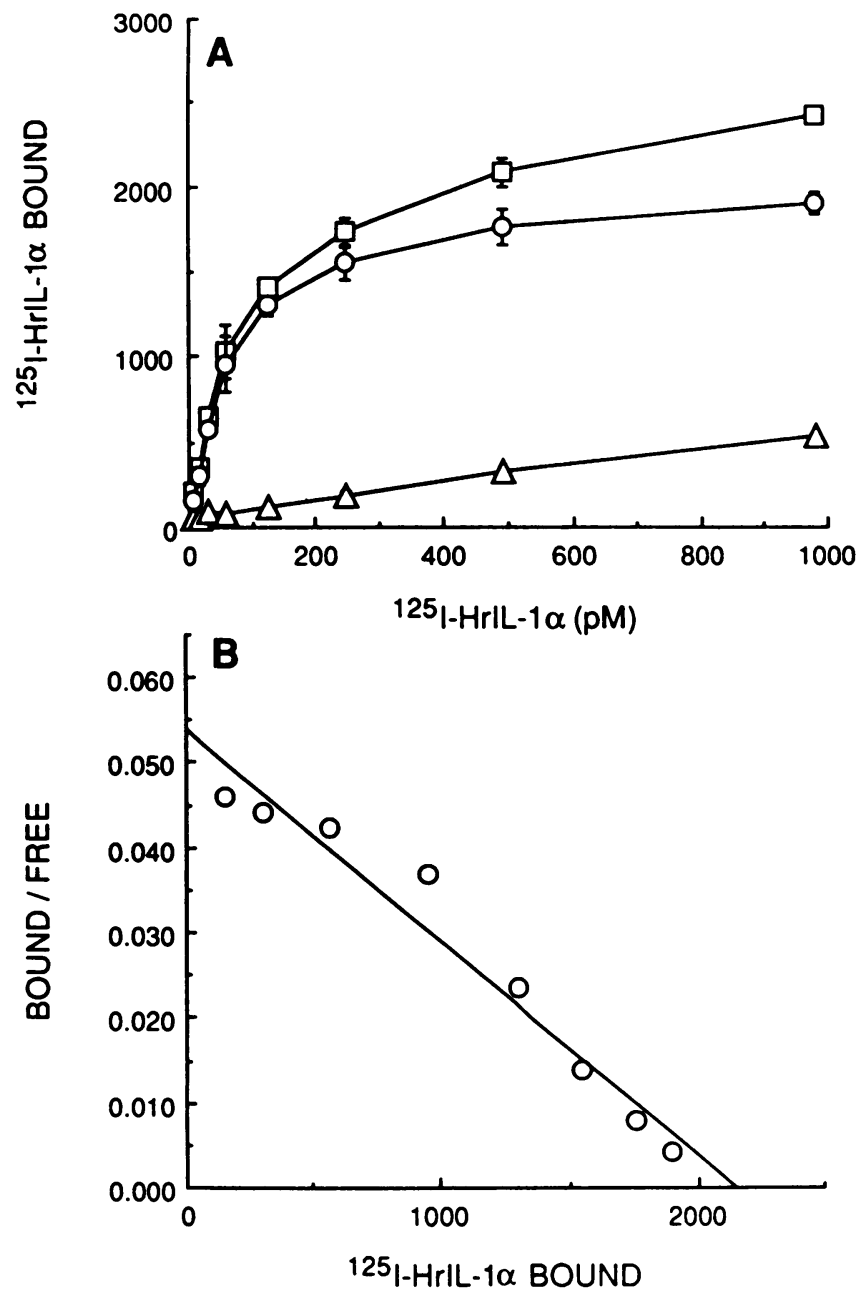

Figure 1. MC3T3 cells express saturable, high-affinity ${ }^{125}$ I-HrIL-1 $\alpha$ binding sites. MC3T3 cells, grown to confluence in 24-well plates, were incubated with varying concentrations of ${ }^{125} \mathrm{I}-\mathrm{HrIL}-1 \alpha$ for $6 \mathrm{~h}$ at $4^{\circ} \mathrm{C}$ in the presence and absence of $20 \mathrm{nM} \mathrm{HrIL}-1 \alpha$. After extensive rinsing, the bound ${ }^{125} \mathrm{I}-\mathrm{HrIL}-1 \alpha$ was released with $1 \mathrm{~N} \mathrm{NaOH}$ and counted. The data represent the mean $(n=2)$ and range of the ${ }^{125} \mathrm{I}$ HrIL-1 $\alpha$ bound/well. $A$ shows the binding curves for the total ( $\square$ ), nonspecific $(\Delta)$, and specific (O) ${ }^{125} \mathrm{I}-\mathrm{H}$ IL $1 \alpha$ bound. $B$ shows the results of Scatchard analysis of the data in $A$.

the DNA amplification step. No amplified product of the appropriate size was detected in either case.

Additional proof that the MC3T3 cells express mature type 1 IL-1R messenger RNA of the expected size, Northern blots of MC3T3 total cell RNA were hybridized with a type 1 IL-1R probe. As the autoradiogram demonstrates (Fig. $2 C$ ), the probe hybridized to a band just above the 28S RNA in a position identical to that observed in EL4 6.1 RNA (20). To exclude the presence of type 2 IL-R mRNA, reverse transcribed MC3T3 total cell RNA was amplified using either type 1 or type 2 IL-1 R primers. As a control, splenocyte total cell RNA was used. As shown in Fig. 3, DNA amplification of both MC3T3 and splenocyte cDNAs with the type 1 IL-1R primers yields products of the expected size that were digestible with Saul indicating the presence of type 1 IL-1 mRNA. In contrast, DNA amplification with the type 2 IL-1R primers failed to yield a product with MC3T3 cDNA but did result in DNA when used with splenocyte cDNA. PvulI digestion of the am- plified (type 2 IL-1R primers) splenocyte cDNA confirmed that it was derived from type 2 IL-1R mRNA. While type 2 IL-1R mRNA sequences in MC3T3 RNA may have been detectable on Southern blots of the PCR gels from these experiments, the fact that we do not have evidence for an alternative IL-1 R by ligand binding together with the inability to observe type 2 IL-1 R mRNA by our PCR technique, a method already greatly exceeding the sensitivity of Northern blots, indicates that this prospect is unlikely.

To determine the relationship between the HrIL- $1 \alpha$ concentrations that stimulate IL- 6 production and the IL-1R $K_{d}$, as well as to determine whether the type 1 IL-1R was mediating this IL-1 effect, MC3T3 cells were exposed to various HrIL-1 $\alpha$ levels in the presence and absence of 35F5. As Fig. $4 \mathrm{~A}$ demonstrates, MC3T3 cells were extremely sensitive to IL-1, with the HrIL- $1 \alpha$ ED $_{50}$ for IL-6 production approximating $0.1 \mathrm{pM}$ and the plateau reached at $1.0 \mathrm{pM}$ HrIL-1 $\alpha$. When the cells were preexposed to $35 \mathrm{~F} 5(5 \mu \mathrm{g} / \mathrm{ml})$ to block the type 1 IL-1 R, there was complete inhibition of MC3T3 IL-6 production in the presence of 1 pM HrIL- $1 \alpha$ (Fig. $4 B$ ). At 100 pM HrIL- $1 \alpha$, the amount of cytokine present was sufficient to overcome the level of receptor blockade due to $35 \mathrm{~F} 5$ and no inhibition of IL-6 production was observed. An equivalent amount of rat IgG had no impact on IL-1-induced IL-6 production. To confirm that the secreted activity was IL-6, the supernatants (1:100) from IL-1-stimulated MC3T3 cells pretreated with media, rat IgG $(5 \mu \mathrm{g} / \mathrm{ml})$, or $35 \mathrm{F5}(5 \mu \mathrm{g} / \mathrm{ml})$ were exposed to anti-IL-6 antibodies before their combination with B9 cells. As Fig. $4 C$ demonstrates, this treatment blocks MC3T3 produced B9 bioactivity, indicating that the secreted factor was indeed IL-6.

The sensitivity of MC3T3 cells to very low levels of IL-1 is consistent with what this cytokine has been observed to do in other systems $(36,37)$. While IL-1 apparently exerts many of its effects by occupying just a fraction of the total receptor number, this cytokine may also enhance its actions by promoting expression of its receptor at low ligand levels. While this hypothesis stands in contrast to previous studies showing that IL-1 downregulates the level of its own receptor expression on lymphocytes and fibroblasts $(38,39)$, we have observed that low levels of IL-1 enhanced IL-1R expression in a T cell line (40). To assess this possibility in MC3T3, cultures were treated with a range of IL- 1 concentrations $(0.1-1,000$ pM HrIL- $1 \alpha)$ for $24 \mathrm{~h}$ followed by ${ }^{125} \mathrm{I}-\mathrm{HrIL}-1 \alpha$ binding. As shown in Fig. 5 , HrIL-1 $\alpha$ levels below the IL-1R $K_{d}(10,1.0 \mathrm{pM})$ increased ${ }^{125} \mathrm{I}-\mathrm{HrIL}-1 \alpha$ binding more than twofold over control cells. Also, high levels $(100,1,000 \mathrm{pM})$ of HrIL-1 $\alpha$ appeared to downregulate ${ }^{125} \mathrm{I}-\mathrm{HrIL}-1 \alpha$ cell surface binding sites in the absence of acid stripping, a treatment that removes IL-1 from cell-surface receptors. After the cells had been acid stripped, however, no decrement in ${ }^{125} \mathrm{I}-\mathrm{H}$ IL- $1 \alpha$ binding by MC3T3 cells treated with high IL-1 levels was observed.

Because $1,25-(\mathrm{OH})_{2} \mathrm{D}_{3}$ is also a very potent bone-resorbing hormone, this steroid was examined for its impact on IL-1R expression by culturing MC3T3 cells in the presence of varying concentrations of $1,25-(\mathrm{OH})_{2} \mathrm{D}_{3}$ or $25(\mathrm{OH}) \mathrm{D}_{3}$ for $24 \mathrm{~h}$. As shown in Fig. 6, the presence of $1,25-(\mathrm{OH})_{2} \mathrm{D}_{3}(50-0.5 \mathrm{nM})$ led to increased MC3T3 ${ }^{125} \mathrm{I}-\mathrm{HrIL}-1 \alpha$ binding that exceeded that exhibited by control cells by $\sim 50 \%$. Additionally, $25(\mathrm{OH}) \mathrm{D}_{3}$ also induced a similar increase in ${ }^{125} \mathrm{I}-\mathrm{HrIL}-\mathrm{l} \alpha$ binding, but the $25(\mathrm{OH}) \mathrm{D}_{3}$ effect required a steroid concentration $3 \log$ orders greater than $1,25-(\mathrm{OH})_{2} \mathrm{D}_{3}$. 

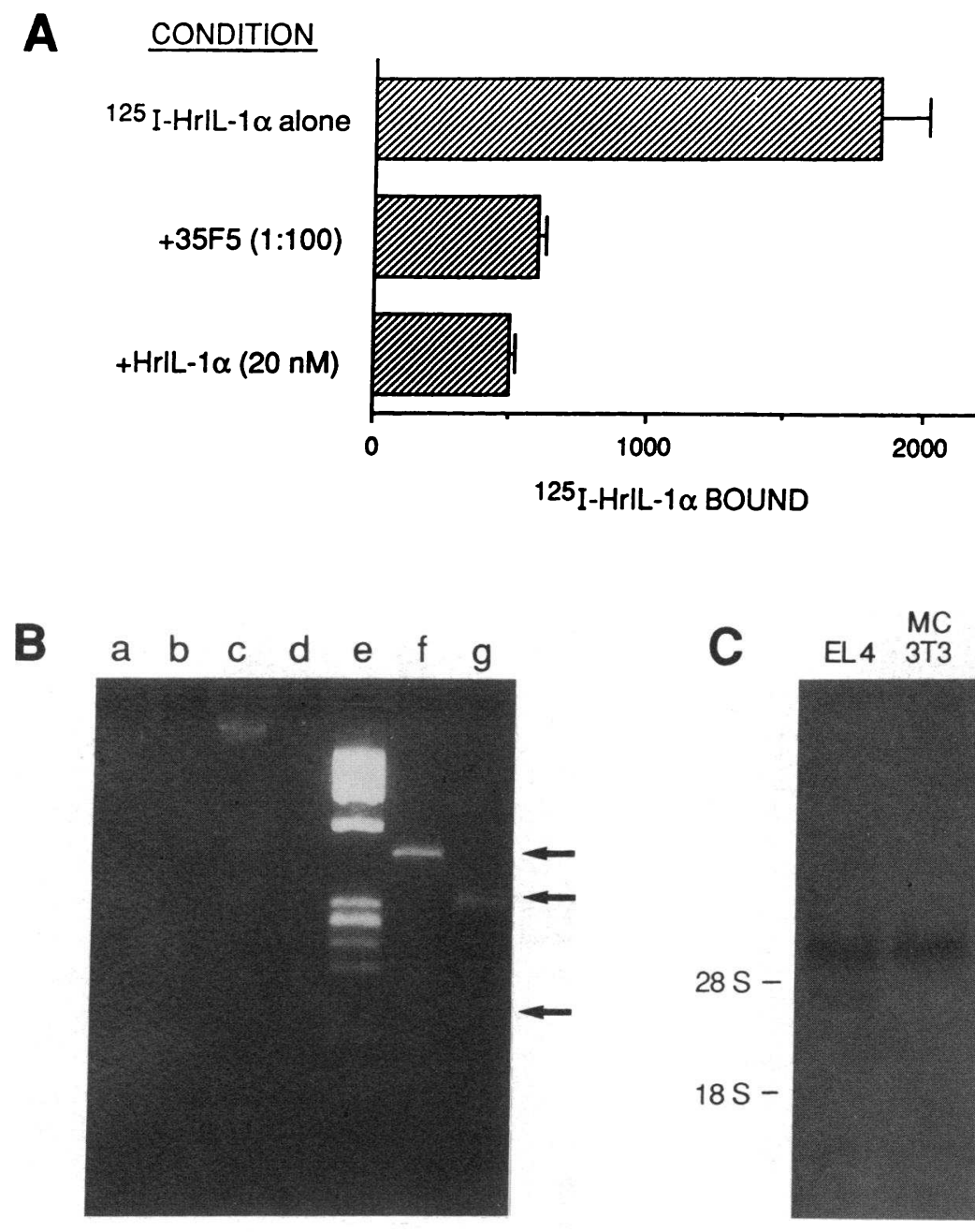

Figure 2. MC3T3 cells express type 1 IL-1 receptors. $(A)$ Confluent cultures of MC3T3 cells in 24-well plate wells were exposed to buffer with no additions, $20 \mathrm{nM}$ HrIL-1 $\alpha$, or 1:100 35F5 (rat anti-murine type $1 \mathrm{IL}-1 \mathrm{R}$ antibody) for $1 \mathrm{~h}$ at $4^{\circ} \mathrm{C}$, after which the wells were exposed to ${ }^{125} \mathrm{I}-\mathrm{HrIL}-1 \alpha(1 \mathrm{nM})$ for an additional $1 \mathrm{~h}$ at $4^{\circ} \mathrm{C}$. The ${ }^{125} \mathrm{I}-\mathrm{HrIL}-1 \alpha$ bound was determined as in Fig. 1 and is expressed as the mean ( $n$ $=2$ ) and range of the ${ }^{125} \mathrm{I}$-HrIL- $\alpha$ bound $/ 1 \times 10^{6}$ cells. $(B)$ MC3T3 total cell RNA ( $1 \mu \mathrm{g})$ was reverse transcribed, amplified, and analyzed in a $3 \%$ agarose gel as described. The primers utilized bracket a 458-bp sequence corresponding to the intracellular domain of the type 1 IL-1R. The samples are as follows: $a$, no added RNA; $b$, RNA with no added reverse transcriptase; $c$, murine genomic DNA; $d$, empty lane; $e$, standard; $f$, RNA; $g$, SauI digest of $f .(C)$ Total cell RNA $(15 \mu \mathrm{g})$ from EL4 6.1 and MC3T3 cells was electrophoresed in formaldehyde-containing $1 \%$ agarose gels, electroblotted, hybridized with ${ }^{32} \mathrm{P}$-labeled type 1 IL-1R DNA probe, and autoradiograms prepared as described. The migration distance of ribosomal RNA is noted.
To address the functional consequence of $1,25-(\mathrm{OH})_{2} \mathrm{D}_{3}-$ induced IL-1 R upregulation on IL- 6 production, MC3T3 cells were treated with $1,25-(\mathrm{OH})_{2} \mathrm{D}_{3}$ for $24 \mathrm{~h}$ to upregulate IL-1R expression, followed by exposure to low concentrations of HrIL- $1 \alpha$. As shown in Fig. $7 A, 1,25-(\mathrm{OH})_{2} \mathrm{D}_{3}$ pretreatment leads to enhanced secretion of IL-1-induced (125, 250 and 1,000 f M HrIL-1 $\alpha$ ) IL-6 bioactivity into MC3T3-conditioned media. To examine whether steady-state levels of IL-6 mRNA were also positively impacted, total cell RNA was collected from MC3T3 cells pretreated with $1,25-(\mathrm{OH})_{2} \mathrm{D}_{3}$ or media alone $(24 \mathrm{~h})$ followed by their exposure to $1 \mathrm{pM} \mathrm{HrIL}-1 \alpha$ for 3 h. Northern blots were prepared and probed with a ${ }^{32} \mathrm{P}$-labeled IL-6 DNA probe. As the autoradiogram shows (Fig. $7 \mathrm{~B}$ ), neither control (lane $a$ ) nor $1,25-(\mathrm{OH})_{2} \mathrm{D}_{3}$ (lane $b$ )-pretreated cells expressed detectable IL-6 mRNA. After an additional 3-h exposure to IL-1 (lanes $d$ and $f$ ) but not control media (lanes $c$ and $e$ ), IL-6 message was detected in both control and 1,25$(\mathrm{OH})_{2} \mathrm{D}_{3}$-pretreated cells. The increase in IL-6 mRNA in $1,25-(\mathrm{OH})_{2} \mathrm{D}_{3}$-pretreated cells (lane $f$ ), however, was greater than the increase seen in control-pretreated (lane $d$ ) cells.

While the immediate effects of IL-1 on resting MC3T3 cells can be attributed to its effects on the type $1 \mathrm{IL}-1 \mathrm{R}$, it is possible that both IL-1 and 1,25-( $\mathrm{OH})_{2} \mathrm{D}_{3}$ augment type 2 as opposed to type 1 IL-1R levels. To determine which IL-1R type(s) was impacted, equilibrium binding studies, antibody-blocking ex- periments, and RT-DNA amplification analysis were performed on control, IL-1 or $1,25-(\mathrm{OH})_{2} \mathrm{D}_{3}$-treated cells or their RNA. Equilibrium ${ }^{125}$ I-HrIL- $1 \alpha$ binding was performed using MC3T3 cells treated with 1 pM HrIL- $1 \alpha, 1,25-(\mathrm{OH})_{2} \mathrm{D}_{3}(5$ $\mathrm{nM}$ ), or control media for $24 \mathrm{~h}$. As shown in Fig. $8 A$, MC3T3 cells treated with either IL-1 or media alone express saturable ${ }^{125} \mathrm{I}-\mathrm{HrIL}-1 \alpha$ binding sites. When the data were resolved by Scatchard analysis (Fig. $8 \mathrm{~B}$ ), the effect of 1 pM HrIL- $1 \alpha$ on MC3T3 ${ }^{125}$ I-HrIL- $1 \alpha$ binding was due to an increase in IL-1R number (control $\mathrm{B}_{\max }=3,189$ receptors/cell; IL-1 $\mathrm{B}_{\max }$ $=7,702$ receptors $/$ cell) with a minimal change in binding site affinity (control $K_{\mathrm{d}}=90$ pM; IL-1 $K_{\mathrm{d}}=162$ pM). Fig. $8 C$ shows that control and $1,25-(\mathrm{OH})_{2} \mathrm{D}_{3}$-treated MC3T3 cells express saturable ${ }^{125} \mathrm{I}-\mathrm{HrIL}-1 \alpha$ binding sites. Scatchard analysis of these data demonstrates (Fig. $8 \mathrm{D}$ ) that the $1,25-(\mathrm{OH})_{2} \mathrm{D}_{3}$ effect on the MC3T3 IL-1R, similar to the effect induced by 1 pM HrIL- $1 \alpha$, is mediated by an increase in receptor number (control $\mathrm{B}_{\max }=6,499$ receptors/cell, 1,25- $(\mathrm{OH})_{2} \mathrm{D}_{3} \mathrm{~B}_{\max }$ $=9,799$ receptors $/$ cell ) without a significant change in receptor affinity (control $K_{\mathrm{d}}=104 \mathrm{pM} ; 1,25-(\mathrm{OH})_{2} \mathrm{D}_{3} K_{\mathrm{d}}$ $=101 \mathrm{pM}$ ).

These data suggested that both HrIL- $1 \alpha$ and $1,25-(\mathrm{OH})_{2} \mathrm{D}_{3}$ increased the expression of a receptor with a similar ${ }^{125} \mathrm{I}-\mathrm{HrIL}-$ $1 \alpha K_{\mathrm{d}}$. To determine whether the increased ${ }^{125} \mathrm{I}-\mathrm{HrIL}-1 \alpha$ binding on HrIL- $1 \alpha$ or $1,25-(\mathrm{OH})_{2} \mathrm{D}_{3}$ treated MC3T3 cells was 


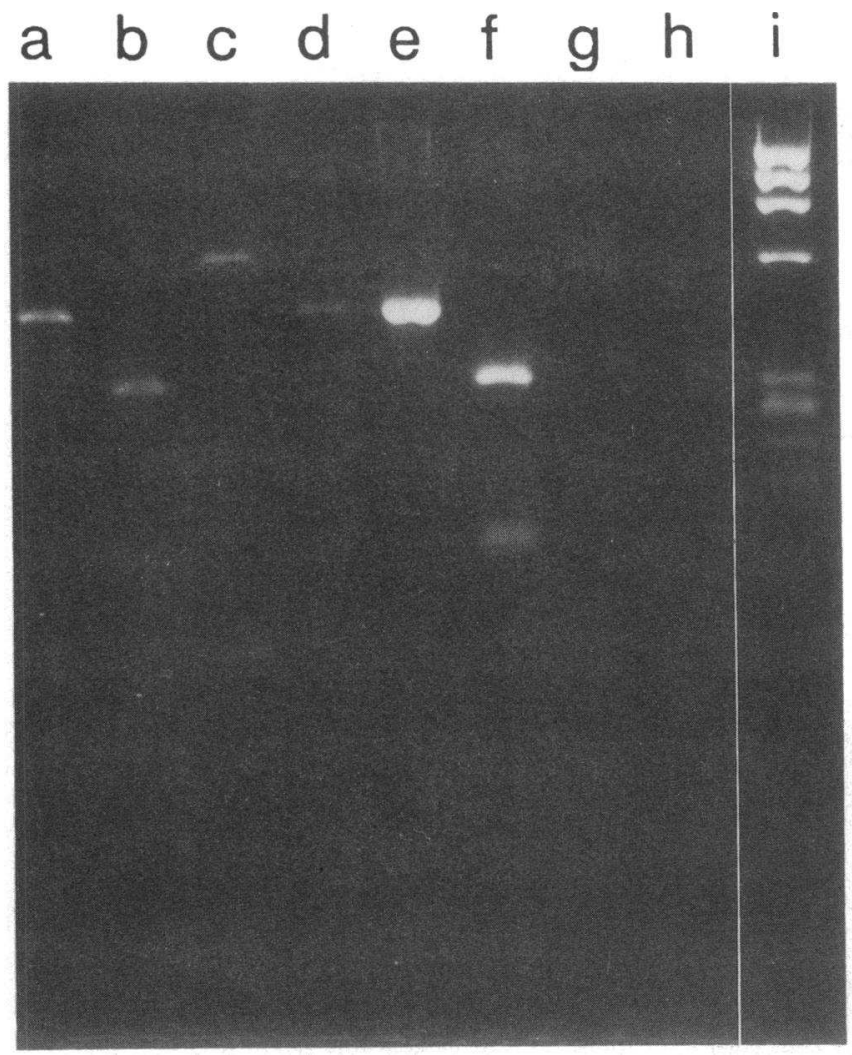

Figure 3. Unstimulated MC3T3 cells do not contain detectable type 2 IL-1R mRNA. MC3T3 and splenocyte total cell RNA ( $2 \mu \mathrm{g})$ were reverse transcribed, divided, and amplified using either the type 1 or type 2 IL-1R primers as described. Aliquots were restriction digested with appropriate enzymes as noted. The samples are as follows: $a$, spleen cell RNA, type 1 IL-1R primers; $b$, SauI digest of $a$; $c$, spleen cell RNA, type 2 IL-1R primers; $d$, PvuII digest of $c$; $e$, MC3T3 RNA, type 1 IL-1R primers; $f$, Saul digest of $e ; g$, MC3T3 RNA, type 2 IL-1R primers; $h$, PvulI digest of $g ; i$, HaelII $\Phi$ X174 restriction fragments.

mediated by elevated type 1 IL-1R levels, ligand-binding experiments were performed on MC3T3 cells treated with these agents, using the type 1 IL-1 R specific monoclonal antibodies 35F5 or unlabeled HrIL- $1 \alpha$ as ${ }^{125}$ I-HrIL- $1 \alpha$ blocking agents. As demonstrated in Fig. $9 A$, 35F5 can block ${ }^{125} \mathrm{I}-\mathrm{HrIL}-1 \alpha$ binding to the same extent as $20 \mathrm{nM} \mathrm{HrIL-1} \alpha$ in control as well as both treatment groups. To exclude the possibility that the type 2 IL-1R gene was induced, but expressed on the cell surface at levels below the sensitivity of our ligand binding method, the impact of HrIL- $1 \alpha(1 \mathrm{pM})$ and $1,25-(\mathrm{OH})_{2} \mathrm{D}_{3}(5 \mathrm{nM})$ on type 1 and type 2 IL-1R mRNA levels in MC3T3 cells was examined, using RT-DNA amplification of RNA obtained from MC3T3 cells. As shown in Fig. $9 \mathrm{~B}$, MC3T3 cells cannot be induced to express type 2 IL-1R mRNA either after a 3- or 24-h exposure to either agent based on this sensitive technique. The murine $T$ cell line RNA used as a control contains mRNA for both the type 1 and type 2 IL-1R consistent with the observations in a recent report describing the cloning of the type 2 IL-1R (21).

Having established the capacity for both HrIL-1 $\alpha$ and 1,25$(\mathrm{OH})_{2} \mathrm{D}_{3}$ to increase MC3T3 type 1 IL-1R expression, the mechanism(s) by which these osteotropic agents effected this change were explored. Time-course experiments were per-
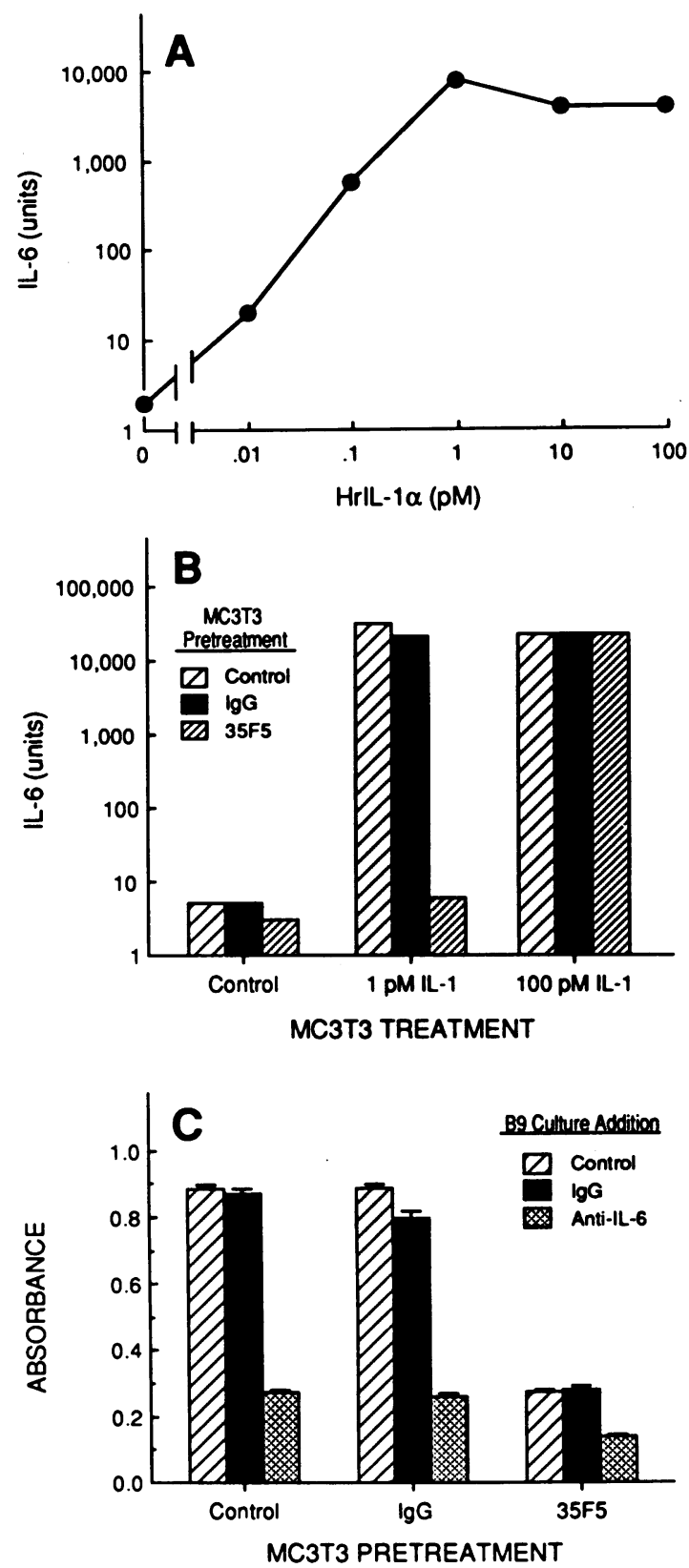

Figure 4. HrIL-1 $\alpha$ stimulates MC3T3 IL-6 production at cytokine levels below the IL-1R $K_{\mathrm{d}}$ through the type 1 IL-1 receptor. $(A)$ HrIL-1 $\alpha$ dose response. Confluent monolayers were exposed to various concentrations of HrIL- $1 \alpha$ for $24 \mathrm{~h}$ and the supernatants were collected and used in the B9 assay as described. The data are expressed in units with the amount of material necessary to stimulate half-maximal B9 proliferation (MTT assay, see Methods) equal to 1 unit. (B) Effect of anti-type 1 IL-1R antibodies on MC3T3 IL-6 production. Confluent cultures were exposed to media alone, rat IgG $(5 \mu \mathrm{g} / \mathrm{ml})$, or $35 \mathrm{~F} 5(5 \mu \mathrm{g} / \mathrm{ml})$ for $30 \mathrm{~min}$ before the addition of media alone or media supplemented with 1 or $100 \mathrm{pM} \mathrm{HrIL-1} \alpha$. The conditioned media were collected and analyzed in the B9 assay as noted in $A$. (C) Anti-IL-6 antibodies inhibit MC3T3-produced B9 stimulatory activity. A 1:100 dilution of IL-1-induced MC3T3 conditioned media was preincubated with anti-IL- 6 antibodies $(1 \mu \mathrm{g} / \mathrm{ml})$, rat $\mathrm{IgG}(1 \mu \mathrm{g} / \mathrm{ml})$ or media alone for $30 \mathrm{~min}$ before the addition of B9 cells. Cellular proliferation was determined using the MTT dye conversion assay and the results are expressed as the mean absorbance at $570 \mathrm{~nm}$ (reference, $630 \mathrm{~nm}$ ) of triplicate wells. The absorbance of unstimulated B9 cells in this experiment was $0.141 \pm 0.015$. 


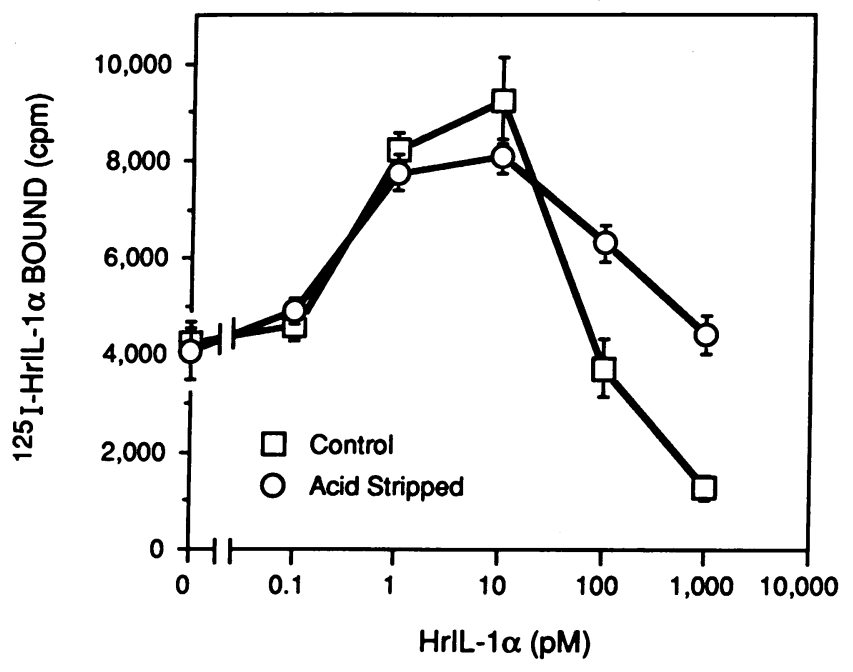

Figure 5. (A) IL-1 influences the expression of its own receptor on MC3T3 cells. MC3T3 cells, at confluency, were exposed to varying HrIL- $\alpha$ levels for a 24-h period. Before ${ }^{125}$ I-HrIL- $1 \alpha$ binding, the cell layers were rinsed with $\mathrm{BB}$ or an acid buffer $(\mathrm{pH}-3.0)$ to remove receptor-bound, culture-derived HrIL- $1 \alpha$ as described. The data represent the mean $(n=3) \pm$ standard deviation of the net ${ }^{125}$ I-HrIL-1 $\alpha$ bound $/ 1 \times 10^{6}$ cells.

formed to define the kinetics of IL-1R upregulation. As Fig. 10 shows, the IL-1 upregulating effect induced by either HrIL- $1 \alpha$ $(1 \mathrm{pM})$ or $1,25-(\mathrm{OH})_{2} \mathrm{D}_{3}(5 \mathrm{nM})$ was not detectable until after 5-7 h of incubation. By $24 \mathrm{~h}$ of incubation with either substance, significant differences in IL-1R expression between the groups became apparent. Also, consistent with other experiments where MC3T3 cells were treated with either $1 \mathrm{pM}$ HrIL$1 \alpha$ or $5 \mathrm{nM} 1,25-(\mathrm{OH})_{2} \mathrm{D}_{3}$ (data not shown), HrIL-1 $\alpha$ treated MC3T3 cells exhibited a greater increase in ${ }^{125}$ I-HrIL-1 $\alpha$ binding than cells treated with $1,25-(\mathrm{OH})_{2} \mathrm{D}_{3}$.

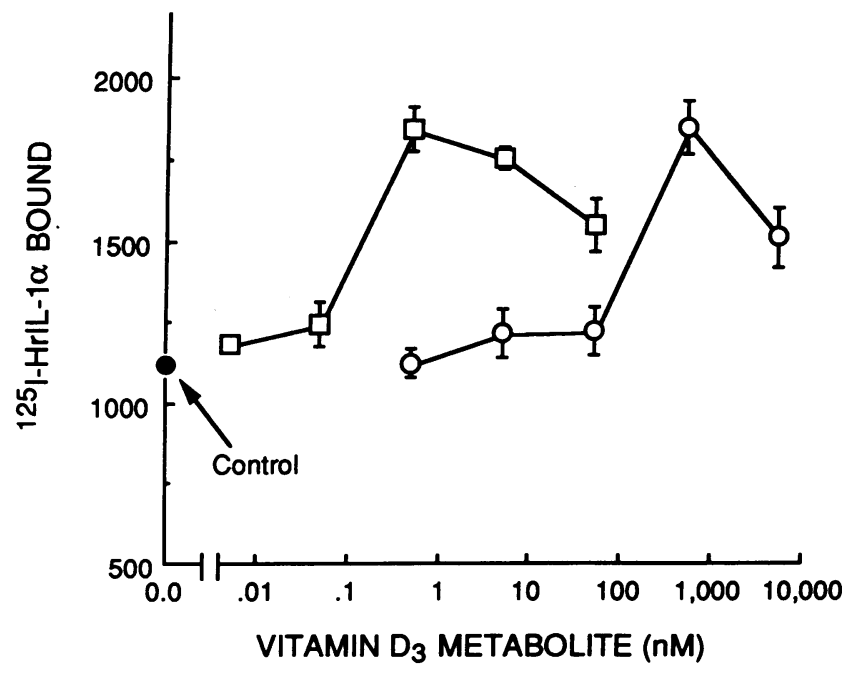

Figure 6. Vitamin $\mathrm{D}_{3}$ augments MC3T3 IL-1 receptor expression in both a dose and metabolite-dependent manner. MC3T3 cells were incubated with various concentrations of $1,25-(\mathrm{OH})_{2} \mathrm{D}_{3}(\square)$ or $25 \mathrm{OHD}_{3}(\mathrm{O})$ for $24 \mathrm{~h}$ and then assessed for ${ }^{125} \mathrm{I}-\mathrm{HrIL}-1 \alpha$ binding as in Fig. 4 except that no acid buffer treatment was employed. The data are expressed as the mean $(n=2)$ and range of the net ${ }^{125} \mathrm{I}$ HrIL- $1 \alpha$ bound $/ 1 \times 10^{6}$ cells.
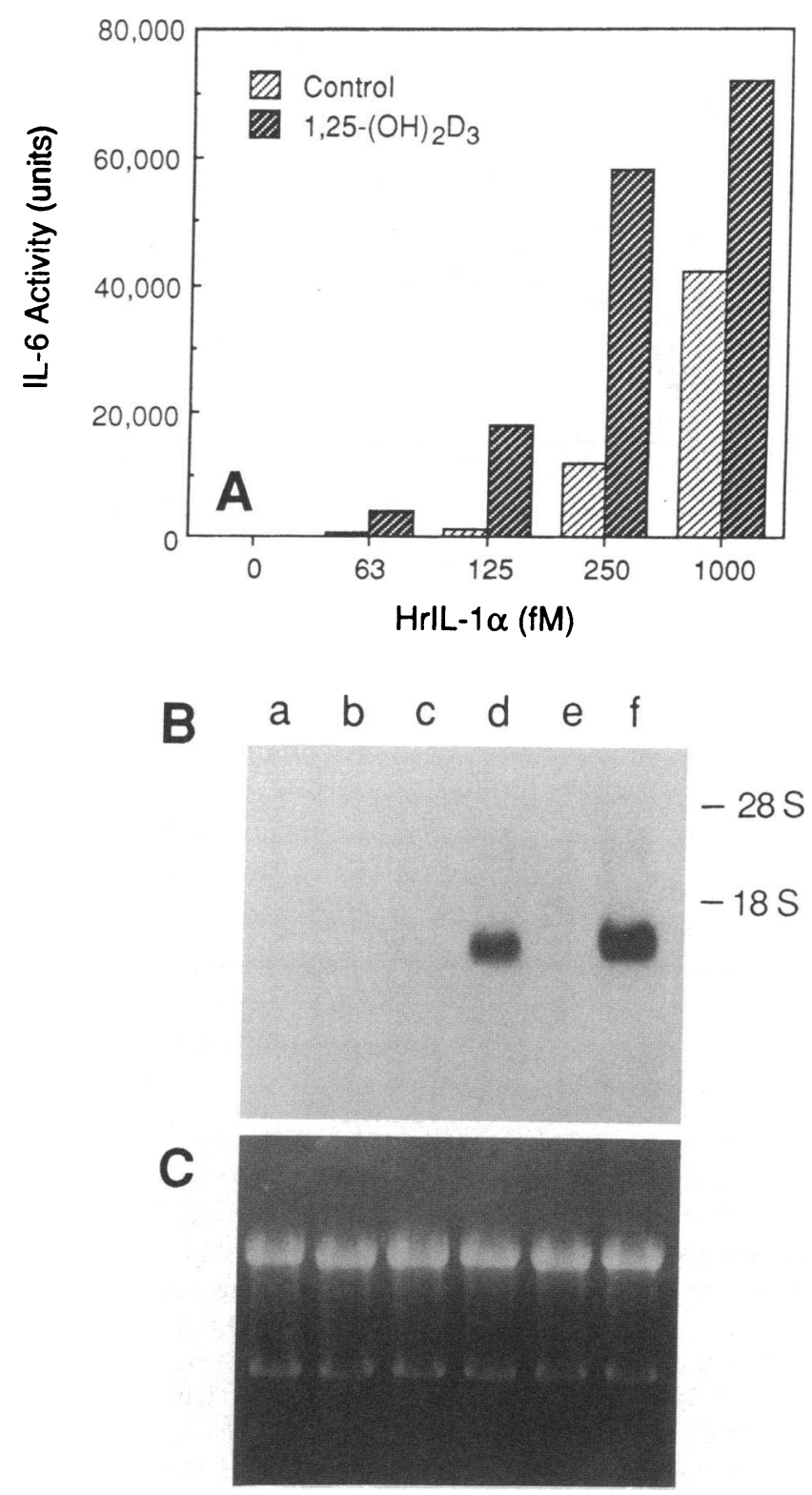

Figure 7. Vitamin $\mathrm{D}_{3}$ pretreatment augments HrIL-1 $\alpha$-induced MC3T3 IL-6 production. $(A)$ MC3T3 bioassayable IL-6 production. MC3T3 cells were treated for $24 \mathrm{~h}$ with media alone or with media

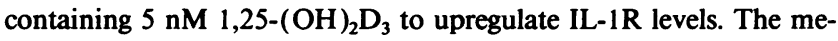
dia was then removed and media alone or media containing various amounts of HrIL- $1 \alpha$ was added for an additional $24 \mathrm{~h}$. The supernatants were collected for use in the B9 assay for IL-6 using the MTT dye conversion assay. The data are expressed as in Fig. $4 A$. (B) MC3T3 IL-6 mRNA expression. Confluent dishes of MC3T3 cells

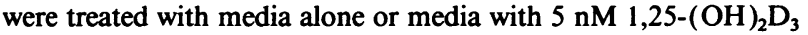
as in $A$. The media were then removed and replaced with media alone or media containing $1 \mathrm{pM}$ HrIL-1 $\alpha$. Total cell RNA was harvested after a 3-h HrIL-1 $\alpha$ exposure and $5 \mu \mathrm{g}$ electrophoresed, blotted, and probed with a ${ }^{32} \mathrm{P}$-labeled murine IL-6 cDNA probe as described. The lanes are as follows: $a$, control pretreated $(C P T X) ; b, 1,25-$ $(\mathrm{OH})_{2} \mathrm{D}_{3}$ pretreated $\left(D_{3} P T X\right) ; c, \mathrm{CPTX}$, control $(3 \mathrm{~h}) ; d, \mathrm{CPTX}$, IL-1 $(3 \mathrm{~h}) ; e, \mathrm{D}_{3}$ PTX, control $(3 \mathrm{~h}) ; f, \mathrm{D}_{3}$ PTX, IL-1 $(3 \mathrm{~h})$. ( $\left.C\right)$ Ethidium bromide-stained gel of $B$.

Because the rise in ${ }^{125} \mathrm{I}-\mathrm{HrIL}-1 \alpha$ binding occurred relatively slowly, it was likely that protein synthesis was involved in both HrIL- $1 \alpha$ and $1,25-(\mathrm{OH})_{2} \mathrm{D}_{3}$ induced IL-1R upregulation. To 


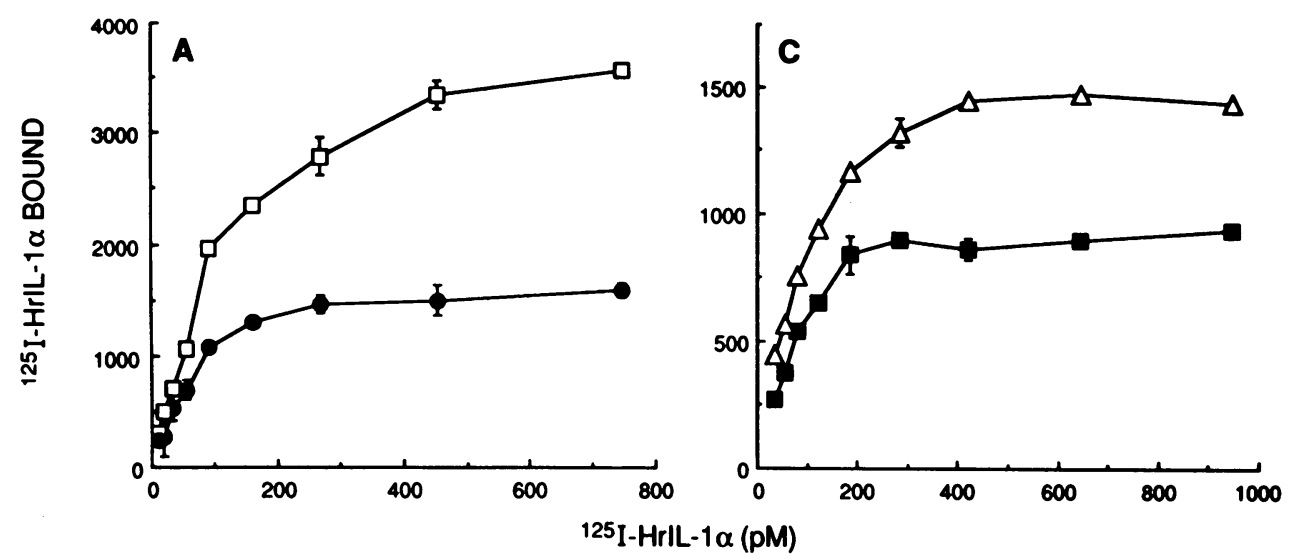

Figure 8 . Equilibrium binding studies of IL-1 - and 1,25$(\mathrm{OH})_{2} \mathrm{D}_{3}$-treated MC3T3 cells. MC3T3 cells, treated for $24 \mathrm{~h}$ with IL-1R upregulating

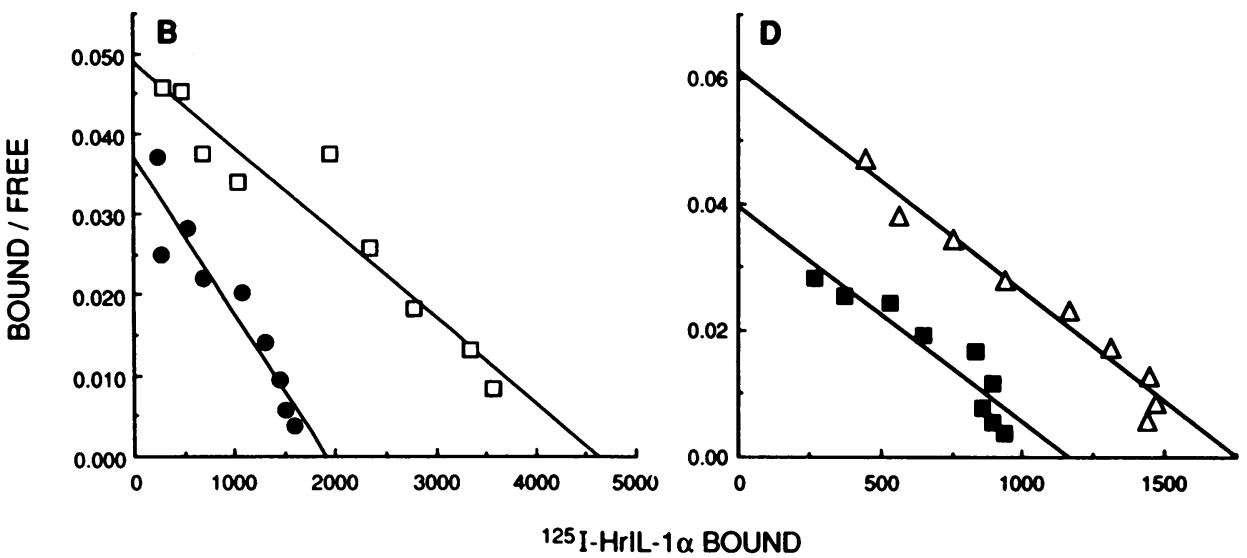
amounts of HrIL-1 $\alpha(1 \mathrm{pM})$ or $1,25-(\mathrm{OH})_{2} \mathrm{D}_{3}(5 \mathrm{nM})$, were assessed for ${ }^{125}$ I-HrIL- $\alpha$ binding as in Fig. 1. $(A)$ The mean $(n=$ 2 ) and range of the net ${ }^{125} \mathrm{I}$ HrIL- $1 \alpha$ bound/well by control $(\bullet)$ and HrIL- $\alpha$ treated cells $(\square)$ are shown. (B) Scatchard plots of the data displayed in $A$ are exhibited. $(C)$ The mean $(n$ $=2$ ) and range of the net ${ }^{125} \mathrm{I}$ HrIL- $1 \alpha$ bound/well by control $(\bullet)$ and $1,25-(\mathrm{OH})_{2} \mathrm{D}_{3}$ treated cells $(\Delta)$ are shown. $(D)$ Scatchard plots of the data displayed in $C$ are exhibited.

confirm this supposition and to define the potential role of DNA transcription in these responses, the effects of $\mathrm{CHX}$ and ACT D on IL-1R expression were characterized. In these experiments, MC3T3 cells were treated for a 24-h period with media alone or with $\mathrm{IL}-1$ receptor upregulating concentrations of either HrIL-1 $\alpha(1 \mathrm{pM})$ or $1,25-(\mathrm{OH})_{2} \mathrm{D}_{3}(5 \mathrm{nM})$ in the presence and absence of either CHX (200 nM) or ACT D ( 80 $\mathrm{nM}$ ). Consistent with the above data, 1 pM HrIL- $1 \alpha$ or $1,25-$ $(\mathrm{OH})_{2} \mathrm{D}_{3} \mathrm{MC} 3 \mathrm{~T} 3$ treatment resulted in significant increases in ${ }^{125}$ I-HrIL- $1 \alpha$ binding (Table II). However, in the presence of either CHX or ACT D, IL-1R upregulation induced by either HrIL- $1 \alpha$ or $1,25-(\mathrm{OH})_{2} \mathrm{D}_{3}$ was abolished. Cell viability was unaffected by the 24-h inhibitor treatment as $>95 \%$ of the cells excluded trypan blue after toxin exposure. Furthermore, the removal of CHX or ACT D from MC3T3 cells followed by the readdition of $1,25-(\mathrm{OH})_{2} \mathrm{D}_{3}$ or HrIL- $\alpha$ for an additional $24 \mathrm{~h}$ revealed that MC3T3 cells could recover and subsequently express increased IL-1Rs ( see Recovery, Table II).

\section{Discussion}

In this study, we have shown that MC3T3 cells express a large number $(3,000-10,000$ receptors/cell $)$ of high-affinity $\left(K_{d}\right.$ $\approx 100$ pM) IL-1 Rs (Fig. 1). Based on the capacity for an antimurine type $1 \mathrm{IL}-1 \mathrm{R}$ monoclonal antibody (35F5) to block virtually all of the specific ${ }^{125} \mathrm{I}-\mathrm{HrIL}-1 \alpha$ binding (Fig. $2 A$ ), together with the presence of type 1 IL-1R mRNA (Fig. 2, $B$ and $C$ ) and absence of type 2 IL-1R mRNA (Fig. 3), we conclude that all of the ${ }^{125}$ I-HrIL- $1 \alpha$ binding on resting MC3T3 cells was due to cell surface type 1 IL-1Rs.
MC3T3 cells increased IL-6 production in response to HrIL- $1 \alpha$ levels well below $(0.1 \mathrm{pM})$ the IL-1R $K_{\mathrm{d}}$ (Fig. 4$)$. The HrIL-1 $\alpha$ sensitivity of MC3T3 IL- 6 production typifies certain IL-1 induced responses observed in other cells. Using an IL-1responsive $\mathrm{T}$ cell line (MD10 cells) derived in our laboratory, we have previously reported that IL-1-driven proliferation occurs at HrIL- $1 \alpha$ levels far below the MD10 IL-1R $K_{\mathrm{d}}(40)$. These observations parallel the results reported for IL-1-stimulated IL-2 production by a murine T lymphoma cell line (36). On the other hand, not all IL-1-driven responses occur at such low ligand concentrations. In MD10 cells, the induction of intracellular alkalinization by HrIL- $\alpha$ requires cytokine levels in the range of the IL-1R $K_{d}(40)$. Further, IL-1 stimulated fibroblast proliferation, which is apparently mediated indirectly through PDGF AA induction (41), also occurs in response to IL-1 levels in the range of the IL-1R $K_{d}(36)$. Hence, IL-1 signaling pathways may be ligand-concentration dependent.

Because IL-1-induced MC3T3 IL-6 production (Fig. 4) and MD10 proliferation (37) had a similar IL-1 concentration dependence, we reasoned that IL-1 per se could increase the level of its expression on MC3T3 cells similar to its effects on the IL-1R expressed by MD10 cells (40). In MD10 cells, HrIL$1 \alpha$ exerts a biphasic effect on its own receptor expression; low concentrations $(<1.0 \mathrm{pM})$ either upregulate or do not affect IL-1R levels, while higher concentrations ( $>10 \mathrm{pM}$ ), approaching the IL-1R K, downregulate IL-1R expression (40). Using HrIL- $1 \alpha$ over a wide concentration range failed to diminish MC3T3 IL-1R levels, including $1 \mathrm{nM}$ HrIL-1 $\alpha$, an amount $1 \log$ order greater than the MC3T3 IL-1R $K_{d}$ (Fig. 5 

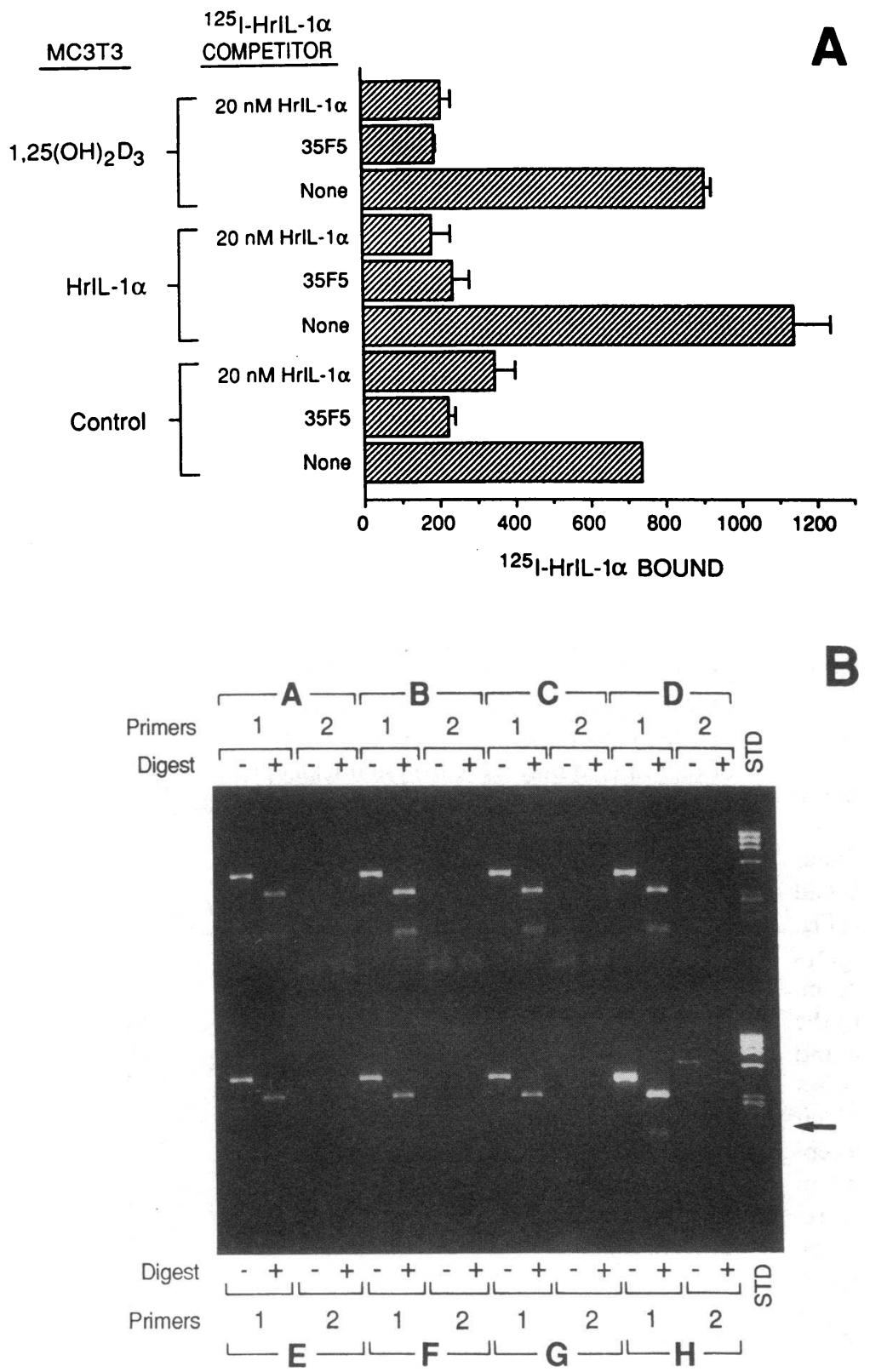

Figure 9. Both 1,25-(OH $)_{2} \mathrm{D}_{3}$ and HrIL-1 $\alpha$ treatments result in elevated MC3T3 type 1 IL-1 R expression. $(A)$ MC3T3 cells were treated with either $5 \mathrm{nM} 1,25-$ $(\mathrm{OH})_{2} \mathrm{D}_{3}$ or $1 \mathrm{pM}$ HrIL- $1 \alpha$ for $24 \mathrm{~h}$. Before ${ }^{125} \mathrm{I}-\mathrm{HrIL}-1 \alpha$ binding, the cells were exposed to $20 \mathrm{nM}$ HrIL-1 $\alpha, 1: 100$ $35 \mathrm{~F} 5$ or buffer alone as in Fig. $2 A$. The data are expressed as the mean $(n=2)$ and range of the cpm ${ }^{125}$ I-HrIL-1 $\alpha$ bound $/ 1 \times 10^{6}$ cells. $(B)$ Confluent MC3T3 cultures were treated with media alone or media supplemented with $1 \mathrm{pM}$ or $5 \mathrm{nM}$ for 3 and $24 \mathrm{~h}$. Total cell RNA was isolated from these cultures and together with control RNA from a murine $T$ cell line subjected to RT-DNA amplification using primers for either the type 1 or type $2 \mathrm{IL}-1 \mathrm{R}$ (denoted as 1 or 2 above) as described (see Methods). Amplified DNA was analyzed in 3\% agarose gels containing ethidium bromide directly $(-)$ or after restriction digestion $(+)$ with either SauI (type 1) or Pvull (type 2). The conditions are as follows: $A$, untreated MC3T3 control; $B-D$, MC3T3 cells treated for 3 $\mathrm{h}$ with media alone, D3, or IL-1, respectively; $E-G$, MC3T3 cells treated for $24 \mathrm{~h}$ with media alone, D3, or IL-1, respectively; $H$, MD10 cell (murine T cell) control The standard ( $S T D$ ) was HaellI $\Phi \times 174$ restriction fragments.

$A$ ). In accordance with our observations of MD10 IL-1R regulation, the exposure of MC3T3 cells to low HrIL-1 $\alpha$ levels led to increased IL-1R expression. In contrast, fibroblastic IL-1 R expression is inhibited by the continuous presence of IL-1 (38, 42). These data suggest that the regulation of IL-1R expression in osteoblastic cells may fundamentally differ from fibroblast IL-1 $R$ regulation, although both cells are derived from connective tissue.

Using primary osteoblast-enriched cultures from neonatal murine calvaria, Shen et al. (26) recently described a high number of IL-1 Rs that appear to be modulated in a manner different from those expressed by MC3T3 cells. In the presence of 2 $\mathrm{ng} / \mathrm{ml}(\sim 100 \mathrm{pM})$ HrIL-1 $\alpha$, IL-1R levels appeared to be diminished after a 24-h treatment (26). Two major differences between their studies and those reported here may explain the discordance between our respective findings. One possibility is that the observed differences reflect unique qualities expressed by a long-term in vitro cell line (MC3T3). However, it is equally probable that the cellular heterogeneity inherent in primary cultures, especially of bone, could have confounded their observations. Furthermore, these authors apparently did not acid-strip their IL-1-treated osteoblast-enriched cultures to remove residual HrIL- $1 \alpha$, although HrIL- $1 \alpha$ levels near the IL$1 \mathrm{R} K_{\mathrm{d}}$ were used in cell treatment. In these conditions, it is likely that a significant number of the cell-surface residing IL$1 \mathrm{R}$ were blocked due to prebound HrIL-1 $\alpha$, making the accurate determination of IL-1 R levels problematic.

Our next series of experiments focused on the possibility that $1,25-(\mathrm{OH})_{2} \mathrm{D}_{3}$ modulated MC3T3 IL-1 R expression. In accordance with our previous observations on MD10 cells (43), 1,25- $(\mathrm{OH})_{2} \mathrm{D}_{3}$ enhanced IL-1 expression in a time (Fig. 8), dose (Fig. 6), and metabolite-specific (Fig. 6) manner. These data, particularly the observed differential in vitamin $\mathrm{D}_{3}$ metabolite potency for IL-1R upregulation, suggest that 1,25 - 


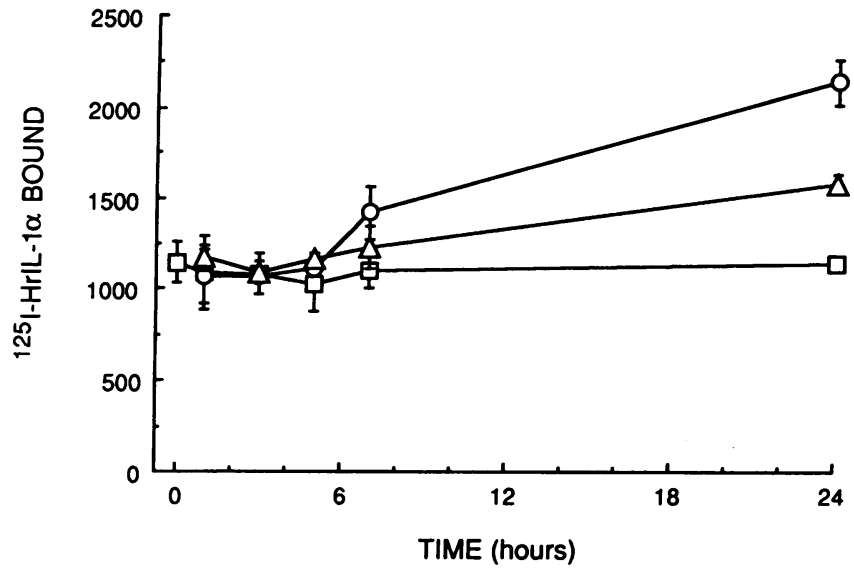

Figure 10. The 1,25- $(\mathrm{OH})_{2} \mathrm{D}_{3}$ and HrIL-1 $\alpha$ upregulating effect on the MC3T3 IL-1 R occurs in a time-dependent manner. MC3T3 cells

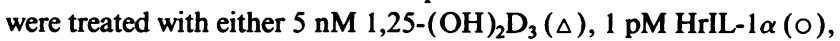
or media alone ( $\square$ ) for varying periods up to $24 \mathrm{~h}$. At selected times, ${ }^{125} \mathrm{I}-\mathrm{HrIL}-1 \alpha$ binding was performed as in Fig. 5 but without acid buffer treatment. The data represent the mean $(n=2)$ and range of the net ${ }^{125} \mathrm{I}-\mathrm{HrIL}-1 \alpha$ bound $/ 1 \times 10^{6}$ cells.

$(\mathrm{OH})_{2} \mathrm{D}_{3}$ mediates its effects on IL-1R levels through the nuclear vitamin $D_{3}$ receptor (44).

To confirm that IL-1R upregulation impacted IL-1 cellular responsiveness, IL- 6 production was examined in cells that had been pretreated with $1,25-(\mathrm{OH})_{2} \mathrm{D}_{3}$ to upregulate IL-1Rs (Fig. $7)$. In the presence of low IL-1 concentrations, $1,25-(\mathrm{OH})_{2} \mathrm{D}_{3}-$ pretreated MC3T3 cells exhibited enhanced IL-6 production. The effect of $1,25-(\mathrm{OH})_{2} \mathrm{D}_{3}$ on MC3T3 cells is similar to the effects of IL-4 on T cells where IL-4 increases IL-1 R levels and also acts synergistically with low concentrations of IL-1 to stimulate cellular proliferation (40). This may be due to a "left shift" in the IL-1 dose-response curve because increased receptor levels, like greater ligand concentrations, may result in more signal-generating receptor-ligand complexes. These results add biologic support to the observations of Curtis et al. (45), who observed that IL-1-induced effects occurred at lower IL-1 levels in Chinese hamster ovary cells engineered to express high levels of the type 1 IL-1R than in control cells that expressed $<100$ type 1 IL- 1 Rs per cell.

The mechanism involved in both the HrIL-1 $\alpha$ and 1,25$(\mathrm{OH})_{2} \mathrm{D}_{3}$ IL-1 $\mathrm{R}$ upregulation involves new protein and RNA synthesis based on inhibitor studies using CHX and ACT D (Table II). Using monoclonal antibodies directed against the murine type 1 IL-1R (23), all of the increases in MC3T3 ${ }^{125} \mathrm{I}$ HrIL- $1 \alpha$ binding induced by either HrIL- $1 \alpha$ or $1,25-(\mathrm{OH})_{2} \mathrm{D}_{3}$ can be attributed to elevated type 1 IL-1R expression (Fig. 9). Furthermore, RT-DNA amplification of RNA obtained from IL-1 - or 1,25-(OH $)_{2} \mathrm{D}_{3}$-treated MC3T3 cells failed to reveal induction of type 2 IL-1R mRNA, indicating that only the type $1 \mathrm{IL}-1 \mathrm{R}$ is expressed in these conditions.

The capacity for HrIL- $\alpha$ and $1,25-(\mathrm{OH})_{2} \mathrm{D}_{3}$ to both increase bone resorption in vitro and in vivo as well as augment MC3T3 IL-1 R expression suggests that osteoblastic IL-1 R regulation may be an important step in bone remodeling. If local IL-1 production characterized certain phases of the resorptive process, then factors that enhance IL-1R expression could serve to "prime" osteoblasts to respond to a subsequent tem- poral burst of IL-1 secretion by secreting increased amounts of IL-6. While it is unclear which cell in the bone microenvironment could provide IL-1, osteoclasts, mononuclear preosteoclasts, or other mononuclear phagocytes are likely candidates because they are members of the monocyte-macrophage family (46-48). Evidence that local IL-1 production occurs in normal animals comes from in situ hybridization studies using probes for IL- $1 \alpha$ and $\beta$ in bone tissue from normal mice (49). In these studies, cells located near the bone surface exhibited a positive hybridization signal for IL $-1 \alpha$, implying that synthesis of IL-1 mRNA occurs normally in the skeleton and suggesting that IL-1 could play a physiologic role in skeletal metabolism.

IL-1's potential role in the pathogenesis of skeletal disease is underscored by the observation that circulating leukocytes from certain subgroups of patients with high-turnover osteoporosis spontaneously secrete large amounts of IL-1 (50). Furthermore, patients with rheumatoid árthritis, a condition characterized by increased local IL-1 production as well as by increased circulating IL-1 levels, frequently suffer both periarticular bone resorption as well as generalized osteoporosis $(51,52)$. While it is unknown if these phenomena are causally linked to the osteoporotic condition, in light of the findings reported here it is possible that low but increased levels of IL-1 in vivo may serve to systemically prime the osteoblastic bone-lining cell population to respond in an exaggerated man-

Table II. CHX and ACT D Effects on MC3T3 IL-IR Expression

\begin{tabular}{llcc}
\hline Condition* $^{*}$ & Inhibitor $^{*}$ & Recovery $^{*}$ & ${ }^{125}$ I-HrIL-1 $\alpha$ Bound" \\
\hline Control & none & - & $1,857 \pm 40^{\prime}$ \\
& CHX & - & $1,691 \pm 111$ \\
& ACT D & - & $1,790 \pm 105$ \\
HrIL-1 $\alpha$ & & & \\
$(1.0 \mathrm{pM})$ & none & - & $4,135 \pm 43$ \\
& CHX & - & $2,009 \pm 165$ \\
& CHX & + & $3,855 \pm 47$ \\
& ACT D & - & $1,733 \pm 106$ \\
$1,25-(\mathrm{OH})_{2} \mathrm{D}_{3}$ & ACT D & + & $3,729 \pm 72$ \\
$(5 \mathrm{nM})$ & & & \\
& none & - & $2,863 \pm 212$ \\
& CHX & - & $1,801 \pm 110$ \\
& CHX & + & $2,475 \pm 252$ \\
& ACT D & - & $1,682 \pm 135$ \\
& ACT D & + & $2,655 \pm 161$
\end{tabular}

* MC3T3 cells were cultured as described for $48 \mathrm{~h}$, after which time the media were changed and the noted amounts of either HrIL-1 $\alpha$ or $1,25-(\mathrm{OH})_{2} \mathrm{D}_{3}$ added.

$\ddagger 1 \mathrm{~h}$ before the addition of the agonists, CHX $(200 \mathrm{nM})$ or ACT D (80 $\mathrm{nM}$ ) was added.

${ }^{5}$ To document the reversibility of the inhibitor effects, paired inhibitor-treated wells were rinsed $(\times 3)$ and the media replaced with fresh media containing the appropriate concentration of the respective agonist and incubated for an additional $24 \mathrm{~h}$.

|| ${ }^{125} \mathrm{I}-\mathrm{HrIL}-1 \alpha$ binding was determined as described (see Methods) after a 24-h treatment with either agonist in the presence and absence of the respective inhibitor. For recovery cultures, ${ }^{125} \mathrm{I}-\mathrm{HrIL}-1 \alpha$ binding was performed after a total of $48 \mathrm{~h}$ of treatment.

' The data are reported as the mean $(n=2) \pm$ the range of the net cpm ${ }^{125} \mathrm{I}$-HrIL-1 $\alpha$ bound $/ 1 \times 10^{6}$ cells. 
ner to transient or sustained increases in locally or systemically produced IL-1. In any event, these studies suggest that osteoblast type 1 IL-1 receptor regulation may represent a key determinant of osteoblast IL-1 responsiveness and therefore mediate the magnitude of IL-1's skeletal effects.

\section{Acknowledgments}

This work was supported by the National Institutes of Health (AI26814, D. L. Lacey), and by the National Osteoporosis Foundation.

\section{References}

1. Rodan, G. A., and T. J. Martin. 1981. Role of osteoblasts in hormonal control of bone resorption. Calcif. Tissue Int. 33:349-351.

2. Gowen, M., and G. R. Mundy. 1986. Actions of recombinant interleukin 1, interleukin 2 , and interferon- $\gamma$ on bone resorption in vitro. J. Immunol. 136:2478-2482.

3. Gowen, M., D. D. Wood, E. J. Ihrie, M. K. B. McGuire, and R. G. G. Russel. 1983. An interleukin-1-like factor stimulates bone resorption in vitro. Nature (Lond.). 306:378-380.

4. Heath, J. K., J. Saklatvala, M. C. Meikle, S. J. Atkinson, and J. J. Reynolds. 1985. Pig interleukin 1 (catabolin) is a potent stimulator of bone resorption in vitro. Calcif. Tissue Int. 37:95-97.

5. Dewhirst, F. E., P. P. Stashenko, J. E. Mole, and T. Tsurumachi. 1985. Purification and partial sequence of human osteoclast activating factor: identity with interleukin 1 beta. J. Immunol. 135:2562-2568.

6. Sabatini, M., B. Boyce, T. Aufdemorte, L. Bonewald, and G. Mundy. 1988 Infusions of recombinant human interleukin $1 \alpha$ and $1 \beta$ cause hypercalcemia in normal mice. Proc. Natl. Acad. Sci. USA. 85:5235-5239.

7. Boyce, B. F., T. B. Aufdemorte, I. R. Garrett, A. J. P. Yates, and G. R. Mundy. 1989. Effects of interleukin-1 on bone turnover in normal mice. Endocrinology. 125:1142-1150.

8. Ohmori, Y., S. Hanazawa, S. Amano, K. Hirose, M. Kumegawa, and S. Kitano. 1988. Effects of recombinant human interleukin $I$ alpha and interleukin 1 beta on cell growth and alkaline phosphatase of the mouse osteoblastic cell line MC3T3-E1. Biochim. Biophys. Acta. 970:22-30.

9. Ikedo, I., M. Kusaka, Y. Hakeda, K. Yokota, M. Kumegawa, and S. Yamamoto. 1988. Effect of interleukin 1 beta on osteoblastic clone MC3T3-El cells. Calcif. Tissue Int. 43:162-166.

10. Evans, D. B., R. A. Bunning, and R. G. Russell. 1990. The effects of recombinant human interleukin-1 beta on cellular proliferation and the production of prostaglandin E2, plasminogen activator, osteocalcin and alkaline phosphatase by osteoblast-like cells derived from human bone. Biochem. Biophys. Res. Commun. 166:208-216.

11. Stashenko, P., F. E. Dewhirst, M. L. Rooney, L. A. Desjardins, and J. D. Heeley. 1987. Interleukin-1 beta is a potent inhibitor of bone formation in vitro. J. Bone Miner. Res. 2:559-565.

12. Sato, K., Y. Fujii, S. Asano, T. Ohtsuki, M. Kawakami, K. Kasono, T. Tsushima, and K. Shizume. 1986. Recombinant human interleukin 1 alpha and beta stimulate mouse osteoblast-like cells (MC3T3-E1) to produce macrophage colony stimulating activity and prostaglandin E2. Biochem. Biophys. Res. Commun. 141:285-291.

13. Canalis, E. 1986. Interleukin-1 has independent effects on deoxyribonucleic acid and collagen synthesis in cultures of rat calvariae. Endocrinology. 118:74-81.

14. Beresford, J. N., J. A. Gallagher, M. Gowen, M. Couch, J. Poser, D. D. Wood, and R. G. G. Russell. 1984. The effects of monocyte-conditioned medium and interleukin 1 on the synthesis of collagenous and non-collagenous proteins by mouse bone and human bone cells in vitro. Biochim. Biophys. Acta. 801:58-65.

15. Kurihara, N., D. Bertolini, T. Suda, Y. Akiyama, and G. D. Roodman. 1990. Interleukin-6 stimulates osteoclast-like multinucleated cell formation in long term marrow cultures by inducing IL-1 release. J. Immunol. 144:42264230.

16. Ishimi, Y., C. Miyaura, C. H. Jin, T. Akatsu, E. Abe, Y. Nakamura, A. Yamaguchi, S. Yoshiki, T. Matsuda, T. Hirano, et al. 1990. IL-6 is produced by osteoblasts and induces bone resorption. J. Immunol. 145:3297-3303.

17. Black, K., I. R. Garrett, and G. R. Mundy. 1991. Chinese hamster ovarian cells transfected with the murine interleukin- 6 gene cause hypercalcemia as well as cachexia, leukocytosis and thrombocytosis in tumor-bearing nude mice. Endocrinology. 128:2657-2659.

18. Roodman, G. D., N. Kurihara, Y. Ohsaki, A. Kukita, D. Hosking, A. Demulder, J. F. Smith, and F. R. Singer. 1992. Interleukin 6. A potential autocrine/paracrine factor in Paget's disease of bone. J. Clin. Invest. 89:46-52.
19. Dower, S. K., S. R. Kronheim, C. J. March, P. J. Conlon, T. P. Hopp, S. Gillis, and D. L. Urdal. 1985. Detection and characterization of high affinity plasma membrane receptors for human interleukin 1. J. Exp. Med. 162:501-515.

20. Sims, J. E., C. J. March, D. Cosman, M. W. Widmer, H. R. MacDonald, C. J. McMahan, C. E. Grubin, J. M. Wignall, J. L. Jackson, S. M. Call, et al. 1988. cDNA expression cloning of the IL-1 receptor, a member of the immunoglobulin superfamily. Science (Wash. DC). 241:585-589.

21. McMahan, C. J., J. L. Slack, B. Mosley, D. Cosman, S. D. Lupton, L. L. Brunton, C. E. Grubin, J. M. Wignall, N. A. Jenkins, C. I. Brannan, et al. 1991. A novel IL-1 receptor, cloned from B cells by mammalian expression, is expressed in many cell types. EMBO (Eur. Mol. Biol. Organ.) J. 10:2821-2832.

22. Bomsztyk, K., J. E. Sims, T. H. Stanton, J. Slack, C. J. McMahan, M. A Valentine, and S. K. Dower. 1989. Evidence for different interleukin 1 receptors in murine B- and T-cell lines. Proc. Natl. Acad. Sci. USA. 86:8034-8038.

23. Chizzonite, R., T. Truitt, P. L. Kilian, A. S. Stern, P. Nunes, K. P. Parker, K. L. Kaf f ka, A. O. Chua, D. K. Lugg, and U. Gubler. 1989. Two high-affinity interleukin 1 receptors represent separate gene products. Proc. Natl. Acad. Sci. USA. 86:8029-8033.

24. Kilian, P., K. Kaff ka, G. Mundy, and L. Bonewald. 1987. Presence and correlation of interleukin-1 receptors on an osteoblastic cell Line SAOS with alkaline phosphatase activity. J. Bone Miner. Res. 2(Suppl.):236. (Abstr.).

25. Goldring. 1989. Biologic effects of interleukin 1 on human osteoblast-like cells are mediated by specific cell receptors. J. Bone Miner. Res. 4(Suppl.):257. (Abstr.).

26. Shen, V., S.-L. Cheng, N. G. Kohler, and W. A. Peck. 1990. Characterization and hormonal modulation of IL-1 binding in neonatal mouse osteoblastlike cells. J. Bone Miner. Res. 5:507-515.

27. Rodan, S. B., G. Wesolowski, J. Chin, G. A. Limjuco, J. A. Schmidt, and G. A. Rodan. 1990. IL-1 binds to high affinity receptors on human osteosarcoma cells and potentiates prostaglandin E2 stimulation of cAMP production. $\mathrm{J}$. Immunol. 145:1231-1237.

28. Sudo, H., H.-A. Kodama, Y. Amagai, S. Yamamoto, and S. Kasai. 1983. In vitro differentiation and calcification in a new clonal osteogenic cell line derived from newborn mouse calvaria. J. Cell Biol. 96:191-198.

29. Kilian, P. L., K. L. Kaffka, A. S. Stern, D. Woehle, W. R. Benjamin, T. M. Dechiara, U. Gubler, J. J. Farrar, S. B. Mizel, and P. T. Lomedico. 1986. Interleukin 1 alpha and interleukin 1 beta bind to the same receptor on T cells. $J$. Immunol. 136:4509-4514.

30. Civitelli, R. C., S. L. Teitelbaum, K. A. Hruska, and D. L. Lacey. 1989. Interleukin-1 activates the $\mathrm{Na}^{+} / \mathrm{H}^{+}$antiport in a murine $\mathrm{T}$ cell. $J$. Immunol. 143:4000-4008.

31. Scatchard, G. 1949. The attraction of proteins for small molecules and ions. Ann. NY Acad. Sci. 51:660-672.

32. Kawasaki, E. 1989. Amplification of RNA sequences via complementary DNA (cDNA). Amplifications. 3:4-6.

33. Chirgwin, J. M., A. E. Przybyla, R. J. MacDonald, and W. J. Rutter. 1979. Isolation of biologically-active ribonucleic acid from sources enriched in ribonuclease. Biochemistry. 18:5294-5299.

34. Chaplin, D. D., D. E. Woods, A. S. Whitehead, G. Goldberger, H. R. Colten, and J. G. Seidman. 1983. Molecular map of the murine S region. Proc. Natl. Acad. Sci. USA. 80:6947-6951.

35. Mosmann, T. 1983. Rapid colorimetric assay for cellular growth and survival: application to proliferation and cytotoxicity assays. J. Immunol. Methods. 65:55-63.

36. Dower, S. K., S. M. Call, S. Gillis, and D. L. Urdal. 1986. Similarity between the interleukin 1 receptors on a murine $\mathrm{T}$ lymphoma cell line and on a murine fibroblast cell line. Proc. Natl. Acad. Sci. USA. 83:1060-1064.

37. Lacey, D. L., J. C. Chappel, and S. L. Teitelbaum. 1987. Interleukin 1 stimulates proliferation of a non-transformed T lymphocyte line in the absence of a co-mitogen. J. Immunol. 139:2649-2655.

38. Mizel, S., P. L. Kilian, J. C. Lewis, K. A. Paganelli, and R. A. Chizzonite. 1987. The interleukin 1 receptor: dynamics of interleukin 1 binding and internalization in T cells and fibroblasts. J. Immunol. 138:2906-2912.

39. Matsushima, K., J. Yodoi, Y. Tagaya, and J. J. Oppenheim. 1986. Down regulation of interleukin 1 (IL-1) receptor expression by IL-1 and fate of internalized 125I-labeled IL-1 beta in a large granular lymphocyte cell line. J. Immunol. 137:3183-3188.

40. Lacey, D. L., and J. E. Erdmann. 1990. IL-1 and IL-4 modulate IL-1 receptor expression in a murine T cell line. J. Immunol. 145:4145-4153.

41. Raines, E. W., S. K. Dower, and R. Ross. 1989. Interleukin-1 mitogenic activity for fibroblasts and smooth muscle cells is due to PDGF-AA. Science (Wash. DC). 242:393-396.

42. Akahoshi, T., J. J. Oppenheim, and K. Matsushima. 1988. Interleukin 1 stimulates its own receptor expression on human fibroblasts through the endogenous production of prostaglandin(s). J. Clin. Invest. 82:1219-1224.

43. Lacey, D. L., J. C. Chappel, and J. E. Erdmann. 1990. 1,25(OH $)_{2} \mathrm{D}_{3}$ augments IL-1 receptor expression by a murine T cell line. J. Bone Miner. Res. 5(Suppl.):266. (Abstr.). 
44. Haussler, M. R. 1986. Vitamin D receptors: nature and function. Annu. Rev. Nutr. 6:527-562.

45. Curtis, B. M., B. Gallis, R. W. Overell, C. J. McMahan, P. DeRoos, R. Ireland, J. Eisenman, S. K. Dower, and J. E. Sims. 1989. T-cell interleukin 1 receptor cDNA expressed in Chinese hamster ovary cells regulates functional responses to interleukin 1. Proc. Natl. Acad. Sci. USA. 86:3045-3049.

46. Dinarello, C. A., and N. Savage. 1989. Interleukin-1 and its receptor. Crit. Rev. Immunol. 9:1-20.

47. Udagawa, N., N. Takahashi, T. Akatsu, H. Tanaka, T. Sasaki, T. Nishihara, T. Koga, T. J. Martin, and T. Suda. 1990. Origin of osteoclasts: mature monocytes and macrophages are capable of differentiating into osteoclasts under a suitable microenvironment prepared by bone marrow stromal cells. Proc. Natl. Acad. Sci. USA. 87:7260-7264.

48. Alvarez, J. I., S. L. Teitelbaum, H. C. Blair, E. M. Greenfield, N. A.
Athanasou, and F. P. Ross. 1991. Generation of avian cells resembling osteoclasts from mononuclear phagocytes. Endocrinology. 128:2324-2335.

49. Takacs, L., E. J. Kovacs, M. R. Smith, H. A. Young, and S. K. Durum 1988. Detection of IL- $1 \alpha$ and IL-1 $\beta$ gene expression by in situ hybridization. Tissue localization of IL-1 mRNA in the normal C57B1/6 mouse. J. Immunol. 141:3081-3095.

50. Pacifici, R., L. Rifas, S. L. Teitelbaum, E. Slatopolsky, R. McCracken, M. Bergfeld, W. Lee, L. V. Avioli, and W. A. Peck. 1987. Spontaneous release of interleukin 1 from human blood monocytes reflects bone formation in idiopathic osteoporosis. Proc. Natl. Acad. Sci. USA. 84:4616-4620.

51. Eastgate, J. A., J. A. Symons, N. C. Wood, F. M. Grinlinton, F. S. D Giovine, and G. W. Duff. 1988. Correlation of plasma interleukin-1 levels with disease activity in rheumatoid arthritis. Lancet. 2:706-709.

52. Sambrook, P. N., and J. Reeve. 1988. Bone disease in rheumatoid arthritis. Clin. Sci. 74:225-230. 